\title{
NMDA Receptor Contribution to the Climbing Fiber Response in the Adult Mouse Purkinje Cell
}

\author{
Claire Piochon, ${ }^{1}$ Theano Irinopoulou, ${ }^{2}$ Daniel Brusciano, ${ }^{1}$ Yannick Bailly, ${ }^{3}$ Jean Mariani, ${ }^{1,4}$ and Carole Levenes ${ }^{1}$ \\ ${ }^{1}$ Université Pierre et Marie Curie-Paris 6, Unité Mixte de Recherche (UMR) 7102, Centre National de la Recherche Scientifique (CNRS), Laboratoire Neurobiologie \\ des Processus Adaptifs, Équipe Développement et Vieillissement du Système Nerveux, 75005 Paris, France, ${ }^{2}$ Unité 536/Unité 706, Inserm, Institut du Fer à Moulin, \\ F-75005 Paris, France, ${ }^{3}$ Neurotransmission et Sécrétion Neuroendocrine, Institut des Neurosciences Cellulaires et Intégratives UMR 7168, CNRS, Université Louis \\ Pasteur, 67084 Strasbourg, France, and 4Hôpital Charles Foix, Assistance Publique-Hôpitaux de Paris, 94 Ivry sur Seine, France
}

Among integrative neurons displaying long-term synaptic plasticity, adult Purkinje cells seemed to be an exception by lacking functional NMDA receptors (NMDA-Rs). Although numerous anatomical studies have shown both NR1 and NR2 NMDA-R subunits in adult Purkinje cells, patch-clamp studies failed to detect any NMDA currents. Using more recent pharmacological and immunodetection tools, we demonstrate here that Purkinje cells from adult mice respond to exogenous NMDA application and that postsynaptic NMDA-Rs carry part of the climbing fiber-mediated EPSC (CF-EPSC), with undetectable contribution from presynaptic or polysynaptic NMDA currents. We also detect NR2-A/B subunits in adult Purkinje cells by immunohistochemistry. The NMDA-mediated CF-EPSC is barely detectable before 3 weeks postnatal. From the end of the third week, the number of cells displaying the NMDA-mediated CF-EPSC rapidly increases. Soon, this EPSC becomes detectable in all the Purkinje cells but is still very small. Its amplitude continues to increase until 12 weeks after birth. In mature Purkinje cells, we show that the NMDA-Rs contribute to the depolarizing plateau of complex spikes and increase their number of spikelets. Together, these observations demonstrate that mature Purkinje cells express functional NMDA receptors that become detectable in CF-EPSCs at $\sim 21 \mathrm{~d}$ after birth and control the complex spike waveform.

Key words: Purkinje cell; cerebellum; development; climbing fiber; complex spike; NMDA

\section{Introduction}

The NMDA receptor (NMDA- $\mathrm{R}$ ) has unique properties that underlie its roles in developmental, physiological, and pathological processes in the brain (for review, see Dingledine et al., 1999; Cull-Candy et al., 2001; Mori and Mishina, 2003). NMDA-Rs are expressed in almost all principal neurons, but, so far, they seemed to be absent from adult Purkinje cells. Thus, these cells are often used as experimental model neurons lacking NMDA-Rs. Although immature rodent Purkinje cells express NR1/NR2-Dcontaining NMDA-Rs (Dupont et al., 1987; Rosenmund et al., 1992; Cull-Candy et al., 1998), there are numerous contradictory findings regarding the actual expression of functional NMDA-Rs by adult Purkinje cells. Using patch clamp, electrophysiologists concluded that Purkinje cells no longer express functional NMDA-Rs after the first postnatal (PN) week (Konnerth et al., 1990; Farrant and Cull-Candy, 1991; Llano et al., 1991). Discrepancies remained, however, with previous studies using intracellular or extracellular current-clamp techniques and showing that

\footnotetext{
Received July 4, 2006; revised Aug. 9, 2007; accepted Aug. 21, 2007.

This work was supported by National Institutes of Health Grant NS34309 and by a 1 year salary provided by the Fondation pour la Recherche Medicale. We thank Dr. Carmen Cifuentes-Diaz for her kind and efficient advice on the immunolabeling study; Drs. Bertrand Lambolez, Jean-Luc Dupont, Ann Lohof, and Fabien Tell for their valuable comments on this study; and Laure and Thibaut for their enthusiastic contribution.

Correspondence should be addressed to Dr. Carole Levenes, Université Pierre et Marie Curie, Équipe Développement et Vieillissement du Système Nerveux, Case Courrier 14, 9 quai St. Bernard, 75005 Paris, France. E-mail: carole.levenes@snv.jussieu.fr.

DOI:10.1523/JNEUROSCI.2422-07.2007

Copyright $\odot 2007$ Society for Neuroscience $\quad$ 0270-6474/07/2710797-13\$15.00/0
}

adult rat or mouse Purkinje cells respond to ionophoretic applications of NMDA (Quinlan and Davies, 1985; Dupont et al., 1987; Billard and Pumain, 1989; Krupa and Crepel, 1990) or providing evidence for functional NMDA-Rs in adult guinea pig Purkinje cells (Kimura et al., 1985; Sekiguchi et al., 1987). Immunohistochemistry or in situ hybridization studies display contradictions as well. Although the NR1 subunit is abundantly expressed by Purkinje cells throughout adulthood (Moriyoshi et al., 1991; Monyer et al., 1992, 1994; Akazawa et al., 1994; Laurie and Seeburg, 1994; Petralia et al., 1994a; Watanabe et al., 1994; Nakagawa et al., 1996; Hafidi and Hillman, 1997), the expression of NR2 in the adult remains unclear: some authors found signal for NR2-A mRNA in rat and human Purkinje cells (Akazawa et al., 1994; Scherzer et al., 1997), whereas others detected no messengers for NR2 (Monyer et al., 1994; Watanabe et al., 1994). Similarly, low immunoreactivity for NR2-A/B proteins was detected in young rats (Petralia et al., 1994b) and adult mice (Yamada et al., 2001), whereas Thompson et al. (2000) found clear NR2-B labeling in Purkinje cells from adult rats and mice, as well as NR2-A labeling in mice only. Beyond differences in the species and techniques, the important remaining question is the age of the animals, i.e., the temporal definition given to adulthood. In the present study, we used mice older than 8 weeks to demonstrate the expression of functional NMDA-Rs in mature Purkinje cells and their contribution to the waveform of the complex spike induced by the stimulation of the climbing fiber (CF). These NMDA-Rs contain NR2-A and/or NR2-B subunits and partici- 
pate in the synaptic currents mediated by the CF in Purkinje cells (CF-EPSCs). We show that the NMDA-mediated CF-EPSC develops with maturation of Purkinje cells, being hardly detectable before postnatal day 21 (P21). In addition, we show that the NMDA-mediated CF-EPSC is half blocked by $10 \mu \mathrm{M}$ 6-cyano-7nitroquinoxaline-2,3-dione (CNQX). These observations explain the apparent lack of NMDA-Rs in Purkinje cell of pre-adult rodents, as observed by some authors, and indicate that NMDA-Rs are important to control the mature CF to Purkinje cell connection.

\section{Materials and Methods}

Care and use of animals. Animal housing and all procedures were performed in accordance with the guidelines of the French Ministry of Agriculture and the European Community. A minimal number of animals was used and handled with maximum care to minimize their suffering

Slice preparation. C57BL/6 mice (Mus musculus; Elevage Janvier, Le Genest-St-Isle, France), aged between $12 \mathrm{~d}$ and 6 months, were used in these experiments. Animals were first anesthetized with halothane and then rapidly decapitated. The cerebellar vermis was immediately removed and cooled to $4^{\circ} \mathrm{C}$ in oxygenated bicarbonate buffered solution (BBS) (see below). Parasagittal $180-\mu \mathrm{m}$-thick slices were cut with a vibratome (VT-1000S; Leica, Wetzlar, Germany). Slices were then incubated for at least $1 \mathrm{~h}$ at room temperature (RT) in the following BBS (in $\mathrm{mm}): 130 \mathrm{NaCl}, 2.5 \mathrm{KCl}, 2.0 \mathrm{CaCl}_{2}, 1.0 \mathrm{MgCl}_{2}, 26.0 \mathrm{NaHCO} 3,1.3$ $\mathrm{NaH}_{2} \mathrm{PO}_{4}$, and 10.0 glucose, $\mathrm{pH} 7.4$ (when bubbled with $95 \% \mathrm{O}_{2}$ and $5 \%$ $\mathrm{CO}_{2}$ ).

Whole-cell recording procedure. The recording chamber was continuously superfused with oxygenated BBS at a rate of $1-2 \mathrm{ml} / \mathrm{min}$, at room temperature. In some experiments indicated in the text, the perfusion solution was warmed to near physiological temperatures $\left(32-35^{\circ} \mathrm{C}\right)$ in the recording chamber. Purkinje cells were visually identified from their position, size, and shape using Nomarski differential interference contrast optics [ $40 \times$ water-immersion lens (Zeiss, Oberkochen, Germany) plus a $2.25 \times$ Nikon (Tokyo, Japan) zoom mounted on an upright Zeiss Axioskop-FS microscope]. Whole-cell voltage- and current-clamp recordings were made with an Axopatch200A amplifier (Molecular Devices, Union City, CA). Signals were filtered at 2 or $5 \mathrm{kHz}$ (low-pass) and usually sampled at 25-37 $\mu$ s. Data acquisition and storage were performed on a personal computer running the ACQUIS1 software (Bio-Logic, Orsay, France). Patch pipettes were made of borosilicate glass capillary tubing pulled on a horizontal puller (Sutter Instruments, Novato, CA) and fire polished (MF-830; Narishige, Tokyo, Japan) to a final resistance of 2-5 M $\Omega$ depending on the internal solution used. The internal solutions used were as follows (in $\mathrm{mm}$ ): $144.0 \mathrm{~K}$ gluconate, $6.0 \mathrm{KCl}, 4.6 \mathrm{MgCl}_{2}, 10.0$ HEPES acid, 10.0 EGTA (or 1.0 for complex spike recordings), 1.0 (or 0.1 in 1 mm EGTA solutions) $\mathrm{CaCl}_{2}, 4.0 \mathrm{ATP}-\mathrm{Na}$, and $0.4 \mathrm{GTP}-\mathrm{Na}$, pH 7.3 adjusted with $\mathrm{KOH}$. In some experiments, including currentvoltage $(I-V)$ curve protocols, the solutions contained the following (in $\mathrm{mM}$ ): 150 Cs-gluconate, $4.6 \mathrm{MgCl}_{2}, 10.0 \mathrm{HEPES}$ acid, 10.0 EGTA, 1.0 $\mathrm{CaCl}_{2}, 4.0 \mathrm{ATP}-\mathrm{Na}$, and $0.4 \mathrm{GTP}-\mathrm{Na}, \mathrm{pH} 7.35$ adjusted with $\mathrm{CsOH}$. In some experiments, we added 1 or $3 \mathrm{~mm}$ of $(5 R, 10 S)-(+)-$ 5-methyl-10,11-dihydro-5H-dibenzo[a,d]cyclohepten-5, 10-imine hydrogen maleate (MK801) to this internal solution to block postsynaptic NMDA-Rs; no differences were detectable between the two concentrations. Series resistances were partially compensated $(70-75 \%)$. Holding potential was set at $-70 \mathrm{mV}$, and liquid junction potential was not corrected (except when otherwise specified). When used, $\mathrm{Mg}^{2+}$-free BBS external solutions were supplemented with $25 \mu \mathrm{M}$ glycine. Bicuculline methiodide (10 or $20 \mu \mathrm{M}$; Sigma, St. Quentin Fallavier, France) was always added to block $\mathrm{GABA}_{\mathrm{A}}$-mediated currents. In the current-clamp mode, a few cells that were spontaneously more depolarized than $-50 \mathrm{mV}$ and that needed large current injection to maintain their membrane potential at $-70 \mathrm{mV}$ were considered to be damaged and were discarded. For ionophoresis experiments, when filled with $10 \mathrm{~mm}$ NMDA, ionophoretic pipettes had a final resistance of 40-50 $\mathrm{M} \Omega$. NMDA was ejected using negative square current pulses ranging from 100 to $250 \mathrm{nA}$. To limit diffusion of NMDA in the BBS, a small positive retention current (usually $10-15 \mathrm{nA}$ ) was continuously applied to the ionophoresis pipette between ejections. Extracellular stimulation of CFs or parallel fibers (PFs) was performed with a constant voltage isolated unit $(0.1 \mathrm{~ms}$ square voltage pulses; $1-90 \mathrm{~V}$ ) through a glass pipette filled with external solution. This pipette was moved around in the granular layer or white matter in the vicinity of the recorded Purkinje cell until the climbing fiber all-or-nothing response was obtained.

Glycine, MK801, 1,2,3,4-tetrahydro-6-nitro-2,3-[f]-quinoxaline-7sulfonamide (NBQX) were from Sigma. NMDA, tetrodotoxin (TTX), CNQX, (RS)-1-aminoindan-1,5-dicarboxylic acid (AIDA), D-(-)-2amino-5-phosphonopentanoic acid (D-APV), and DL-threo- $\beta$ benzyloxyaspartic acid (DL-TBOA) were from Tocris Bioscience (distributed by Fisher Bioblock Scientific, Illkirch, France).

To estimate whether a cell displays a detectable D-APV-sensitive NBQX-resistant EPSC, the amplitudes of the NBQX-resistant EPSCs in control and their amplitudes during bath application of D-APV were compared using a Mann-Whitney one-tailed statistical test. If the two populations of amplitudes (control and D-APV) were statistically different $(p>0.05)$, D-APV was considered as having an effect, and the percentage of blockade induced by D-APV was calculated.

For analysis of complex spikes, spikes and spikelets were first identified with a threshold detection protocol (usually $20 \mathrm{mV}$ ). Spike or spikelet latencies were estimated by calculating the time between the stimulation and the occurrence of the spike or spikelets.

Immunohistochemistry. Parasagittal $60 \mu \mathrm{m}$ slices were prepared as described previously in a slicing sucrose BBS (in mM: $1 \mathrm{CaCl}_{2}, 5 \mathrm{MgCl}_{2}, 10$ glucose, $4 \mathrm{KCl}, 26 \mathrm{NaHCo}_{3}, 248$ sucrose, and $1.3 \mathrm{NaH}_{2} \mathrm{PO}_{4}, \mathrm{pH} 7.35$ ) cooled to $4^{\circ} \mathrm{C}$ and bubbled with $95 \% \mathrm{O}_{2}$ and $5 \% \mathrm{CO}_{2}$. Immediately after slicing, the slices were fixed with $4 \%$ paraformaldehyde in PBS for $2 \mathrm{~h}$. They were then rinsed three times with PBS. Permeabilization and saturation were performed during $1 \mathrm{~h}$ on free-floating sections with PBS containing $0.25 \%$ Triton X-100 and $0.25 \%$ fish gelatin (PBS-G-T). Three types of anti-NR2 antibodies were used: (1) rabbit anti-NR2-D raised against amino acids 268-386 of human NR2-D; (2) goat anti-NR2-C/D raised against a peptide mapping at the $\mathrm{C}$ terminus of NR2-D of mouse; it also recognizes NR2-C (sc-1471; Santa Cruz Biotechnology, distributed by Tebu, Le Perray en Yvelines, France); and (3) rabbit anti-NR2$\mathrm{A} / \mathrm{B}$ raised against the $\mathrm{C}$ terminus of the rat NR2-A subunit. It recognizes both NR2-A and NR2-B mouse proteins equally (AB1548; Chemicon, Temecula, CA, distributed by Euromedex, Mundolsheim, France). The anti-NR2-C/D or anti-NR2-D antibodies were used only in singlelabeling experiments and were revealed with Alexa Fluor 546 rabbit antigoat or goat anti-rabbit antibodies ( $10 \mu \mathrm{g} / \mathrm{ml}$; Invitrogen, Carlsbad, CA), following the procedure detailed hereafter. For NR2-A/B immunodetection, slices were divided into three batches and incubated overnight at room temperature in the following combinations: batch 1 with only the rabbit anti-NR2-A/B antibody $(1 \mu \mathrm{g} / \mathrm{ml})$; batch 2 incubated with NR2A/B, mouse anti-calbindin-D28k (1:10000; Swant, Bellizona, Switzerland), and guinea pig anti-vesicular glutamate transporter 2 (VGluT2) (1:3000; Chemicon) antibodies; and batch 3 incubated with PBS-G-T only (control). Slices were then incubated $2 \mathrm{~h}$ with the fluorescent secondary antibodies (at $10 \mu \mathrm{g} / \mathrm{ml}$; Invitrogen): Alexa Fluor 546 goat antirabbit (batches 1-3), Alexa Fluor 633 goat anti-mouse and Alexa Fluor 488 goat anti-guinea pig (batches 2 and 3 ). In some experiments, sheep anti-rabbit IgG cyanine 3-coupled (Cy3) (Sigma) was also used as a secondary antibody to reveal NR2-A/B. The labeled slices were mounted in Vectashield medium (Vector Laboratories, Burlingame, CA) and viewed with a confocal laser-scanning microscope (SP2; Leica, Manheim, Germany) using a $63 \times$ objective. In multiple-labeling experiments, acquisition of the signal was systematically performed in sequential mode. Alexa Fluor 488 was excited at $488 \mathrm{~nm}$ (argon laser), Alexa Fluor 546 and Cy3 dye at $543 \mathrm{~nm}$ (helium-neon laser), and Alexa Fluor 633 at $633 \mathrm{~nm}$ (helium-neon laser).

Three-dimensional reconstructions were performed using the Imaris-4 software (Bitplane, Zurich, Switzerland).

Statistics. Averages are given as mean \pm SEM. Mann-Whitney or Wil- 
coxon's tests were used for statistical comparisons, and $p$ is given as the probability of the null hypothesis.

\section{Results \\ Bath or ionophoretic applications of NMDA induce currents in Purkinje cells}

Purkinje cells from animals older than 8 weeks were voltage clamped at $-70 \mathrm{mV}$ in the whole-cell patch-clamp configuration (see Materials and Methods). NMDA was applied in the bath for $1 \mathrm{~min}$ in the presence of NBQX $(10 \mu \mathrm{M})$, TTX $(1 \mu \mathrm{M})$, and bicuculline $(20 \mu \mathrm{M})$. In these conditions, NMDA elicited inward currents in all the Purkinje cells tested $(n=16)$, with a mean amplitude of $38 \pm 6.4,110 \pm 20.8$, and $115 \pm 56.1 \mathrm{pA}$ for 20, 50, and $100 \mu \mathrm{M}$ NMDA, respectively (Fig. $1 A$ ). NMDA was also applied locally using the ionophoresis technique, always in the presence of NBQX, TTX, and bicuculline at the same concentration as above. Applications at the level of the upper third part of the dendrites generally elicited no response unless using long-lasting ejections (for instance $1 \mathrm{~s}$ ). Applications at the level of the lower two-thirds of the Purkinje cell dendrites generated large inward currents of $349.9 \pm 54.9 \mathrm{pA}$ $(n=8)$ that were completely abolished by D-APV $(n=4)$ (Fig. $1 B)$ or by external $\mathrm{Mg}^{2+}(n=4)$. These currents could reach $>800$ pA by increasing the ejection time. We preferred, however, working on smaller responses to limit diffusion of the NMDA. Thus, all tested Purkinje cells of adult mice respond to exogenous application of NMDA.

With slow methods of agonist application, like bath application, if the receptors involved are rapidly desensitizing, the resulting currents are very small. The fact that the NMDA current is very small during our bath application experiments compared with that induced by ionophoresis indicates strong desensitization of the response. Thus, the NMDA-Rs demonstrated here are unlikely to contain the neonatal NR2-D subunits that are known to display particularly low desensitization (Misra et al., 2000). Because of their biophysical features, NR2-D subunits are not compatible with synaptic currents (Misra et al., 2000), whereas other NR2 subunits are involved in NMDA-mediated synaptic transmission. It was therefore of interest to test the participation of the NMDA-Rs demonstrated here in the synaptic transmission of adult Purkinje cells.

\section{PF-EPSCs display no NMDA component}

The participation of some NMDA-Rs in EPSCs of Purkinje cells was examined in nominal $\mathrm{Mg}^{2+}$-free solution to prevent NMDA-R blockade by external $\mathrm{Mg}^{2+}$ ions. PF-EPSCs, elicited by extracellular stimulation at 3 or $5 \mathrm{~s}$ intervals in the molecular layer, were identified by their graded amplitude increasing with stimulus intensity and by their characteristic paired-pulse facilitation in response to $30 \mathrm{~ms}$ interval paired stimulations (Konnerth et al., 1990). PF-EPSCs were inhibited by $10 \mu \mathrm{M}$ NBQX in the bath $(n=7)$ (Fig. $1 C)$. In a few cells $(n=4)$, a small EPSC $(\sim 30 \mathrm{pA})$ persisted in the presence of NBQX but was not further blocked by D-APV. Thus, low-frequency-evoked single PFEPSCs display no detectable NMDA component.

\section{CF-EPSCs display an NMDA component}

CF-EPSCs were elicited by $30 \mathrm{~s}$ interval extracellular stimulation in the granular layer and could be identified by their all-or-none nature, very large amplitude, and paired-pulse depression (PPD) (40 ms interval) (Konnerth et al., 1990). CFEPSCs during control periods were acquired at $-70 \mathrm{mV}$ (liquid junction uncorrected), in nominal $\mathrm{Mg}^{2+}$-free solution and in the presence of 100 or $500 \mathrm{~nm}$ NBQX to reduce voltageclamp escape attributable to the very large amplitude of CFEPSCs (Fig. 1D). In contrast to PF-EPSCs, adding $10 \mu \mathrm{M}$ NBQX to the bath did not completely abolish CF-EPSCs. A residual CF-EPSC of $228.9 \pm 25$ pA persisted in 46 of 47 adult Purkinje cells tested (Figs. $1 D, 2$ ). This NBQX-resistant CFEPSC was all or none and displayed PPD. D-APV $(50 \mu \mathrm{M})$ and $\mathrm{Mg}^{2+}(1 \mathrm{mM})$, respectively, blocked $87 \pm 5.5 \%(n=9)$ (Fig. $2 A)$ and $72.6 \pm 4 \%(n=10)$ (Fig. $2 B)$ of this NBQX-resistant EPSC. The washout of D-APV allowed this NBQX-resistant CF-EPSC to fully recover (Fig. $2 \mathrm{~A}$ ).

\section{The NMDA-mediated CF-EPSC does not result from the indirect activation of AMPA/kainate receptors, metabotropic glutamate receptors type $1, \mathrm{GABA}_{\mathrm{A}}$ receptors, or glutamate transporters}

Purkinje cells respond to exogenous application of NMDA in the presence of NBQX, bicuculline, and TTX in the bath, i.e., when the contribution of polysynaptic NMDA currents is strongly reduced. This suggests that, surprisingly enough, these cells express NMDA-Rs. This is further supported by the existence of an NMDA-mediated component in the CF-EPSC. However, considerable previous evidence indicated that NMDA-Rs are not, or very weakly, expressed by adult Purkinje cells (Crepel et al., 1982; Garthwaite et al., 1987; Konnerth et al., 1990; Krupa and Crepel, 1990; Farrant and Cull-Candy, 1991; Llano et al., 1991). If this is true, the NMDA-mediated CF-EPSC evidenced here has to be of presynaptic origin. How could presynaptic NMDA-Rs carry part of the CF-EPSC? One possibility lies in the indirect activation of presynaptic NMDA currents, located at both inhibitory and excitatory terminals. The stimulation of a single climbing fiber causes the simultaneous release of multiple glutamate vesicles at numerous release sites (Wadiche and Jahr, 2001). The resulting spillover of glutamate could activate some presynaptic NMDA-Rs, located on parallel fibers (Petralia et al., 1994a,b) (but see Diez-Garcia et al., 2005; Shin and Linden, 2005) or inhibitory interneurons (Glitsch and Marty, 1999; Clark and Cull-Candy, 2002). These presynaptic NMDA-Rs would then drive the release of glutamate from parallel fibers or GABA from interneurons. GABA mediates currents in Purkinje cells during bath applications of NMDA (Llano et al., 1991; Glitsch and Marty, 1999). In the present study, however, all applications of NMDA were made in the continuous presence of TTX, bicuculline, and NBQX, and thus, $\mathrm{Na}^{+}$action potentials, $\mathrm{GABA}_{\mathrm{A}}$, and AMPA/kainate receptor-mediated currents were blocked. In these conditions, the contribution of polysynaptic NMDA-associated currents is strongly reduced, if not completely eliminated. In addition, during the application of exogenous NMDA, we never observed any miniature inward currents, which, in summation, could have accounted for the NMDA current (Llano et al., 1991). Finally, the existence of $\mathrm{GABA}_{\mathrm{A}}$-mediated currents in Purkinje cells is very unlikely here, because, in addition to bicuculline in the bath, recordings were made with low chloride concentration-based internal solutions. The total estimated chloride concentrations were 5.6 and $15.4 \mathrm{~mm}$, respectively, for Cs- and K-based solutions. In these conditions, at approximately $-70 \mathrm{mV}$, chloride currents are either outward or their driving force is low. Thus, in the Purkinje cell recorded here, the contribution of GABA-mediated currents to the NMDA inward current is either absent or strongly reduced.

Another possibility involves the contribution of NMDA-Rs located at parallel fibers (see above). In this hypothesis, some 


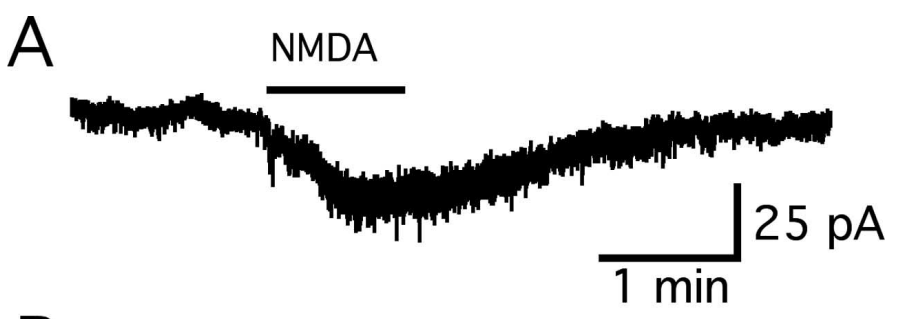

B
Control

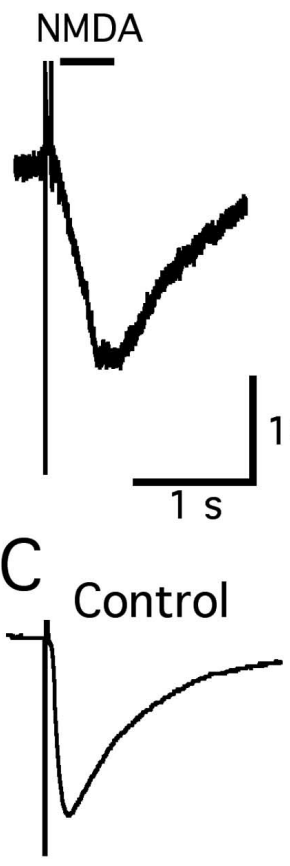

$100 \mathrm{pA}$

$1 \mathrm{~s}$

$\mathrm{D}$

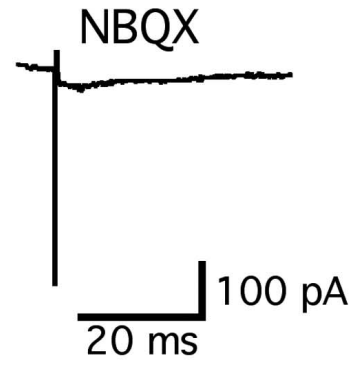

D-APV

NMDA

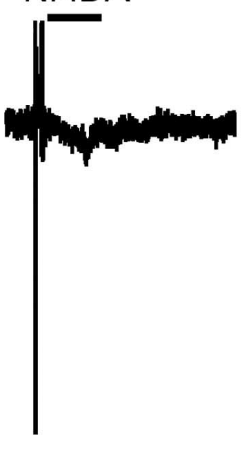

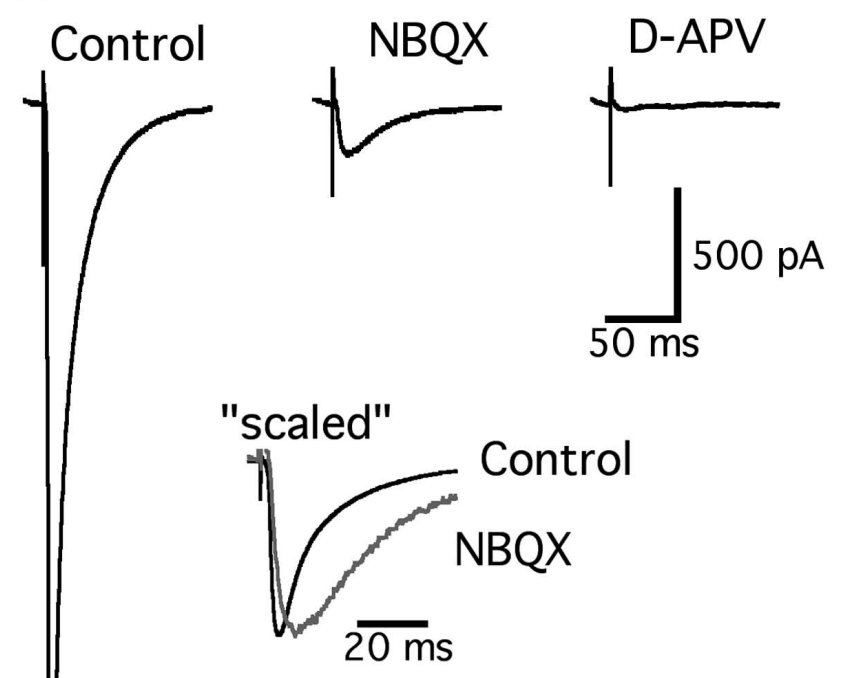
contribution to the climbing fiber EPSC. $\boldsymbol{A}$, Bath application of $50 \mu \mathrm{m}$ NMDA performed in the presence of NBQX (10 $\mu \mathrm{M})$, bicuculline $(20 \mu \mathrm{M})$, and TTX (1 $\mu \mathrm{M})$. $\boldsymbol{B}$, Inward currents induced by ionophoretic applications of NMDA (left) are completely blocked by $50 \mu \mathrm{m}$ D-APV (right). Re- presynaptic NMDA-Rs located at parallel fibers could drive the release of glutamate that could, in turn, activate different targets on Purkinje cells, such as AMPA/kainate receptors, metabotropic glutamate receptors type 1 (mGluR1), and glutamate transporters. Concerning the two first candidates, $50 \mu \mathrm{M}$ NBQX $(n=4)$ or the group I mGluR antagonist AIDA $(100 \mu \mathrm{M} ; n=3)$ (Fig. 2D) have no effect on the NBQX-resistant CF-EPSC. Glutamate transporters deserve specific attention because they have been shown to mediate an NBQX-resistant CF-EPSC (Otis et al., 1997; Auger and Attwell, 2000). Therefore, we blocked glutamate transporters with DL-TBOA, a specific and nontransported glutamate transporter blocker that does not induce glutamate release by heteroexchange (Shimamoto et al., 1998). When applied to Purkinje cells, DL-TBOA (100 $\mu \mathrm{M}$ in the bath) did not block but, in fact, increased the amplitude of the NMDA-mediated CF-EPSCs from $238.1 \pm 24.5 \mathrm{pA}$ in the control period to $402.6 \pm 75 \mathrm{pA}(n=$ 5, Wilcoxon's test, $p<0.05$ ) (Fig. $2 C$ ). These potentiated responses were blocked by D-APV $(50 \mu \mathrm{M})$, showing that they were carried by NMDA-Rs (Fig. 2C). Thus, the NMDA-mediated CFEPSC does not result from the indirect activation of AMPA/kainate receptors, mGluR1, or glutamate transporters in Purkinje cells.

The large potentiation of the NMDA-mediated CF-EPSCs observed in the presence of DL-TBOA shows that glutamate transporters limit the amplitude of these currents, raising the possibility that the NMDA-mediated CF-EPSC would be strongly reduced or even absent at physiological temperatures (because of enhanced glutamate uptake). To test this, we raised the temperature of the bath to $32-35^{\circ} \mathrm{C}$ and estimated the relative contribution of the NMDA-mediated current to the total NBQX-resistant CF-EPSC by adding D-APV at the end of the recordings. To calculate the true NMDA-mediated CF-EPSC, the amplitude of the CF-EPSC recorded in NBQX plus D-APV was subtracted from the CF-EPSC in NBQX alone. As illustrated in supplemental Figure $1 A$ (available at www. jneurosci.org as supplemental material), the mean NBQXresistant CF-EPSC was increased in amplitude (397.6 \pm 58.8 $\mathrm{pA} ; n=5$ ) when compared with RT (usually $25^{\circ} \mathrm{C}$ ) experiments $(261.6 \pm 45.3 ; n=8 \mathrm{pA})$. However, the relative NMDAdependent component remained the same at both temperatures (supplemental Fig. $1 B$, available at www.jneurosci.org as supplemental material) $\left(196.6 \pm 80.1, n=5\right.$ at $32-35^{\circ} \mathrm{C}$ vs $212.5 \pm 44.3 \mathrm{pA}, n=8$ at $\mathrm{RT}$ ). The remaining NBQX-resistant CF-EPSC that is potentiated at $32-35^{\circ} \mathrm{C}$ and that is not mediated by NMDA-Rs probably corresponds to the CF-EPSC carried by glutamate transporters (Otis et al., 1997; Auger and Attwell, 2000; Huang et al., 2004). Thus, even at more physiological temperature, CF-EPSCs display a clear and constant NMDA-mediated current, which indicates that glutamate transporters do not prevent the activation of NMDA-Rs located at climbing fiber to Purkinje cell connections.

These observations indicate that some NMDA-Rs of Purkinje cells are located relatively close to climbing fiber terminals. In addition, because of the potentiating effect of DL-TBOA, there might also be additional NMDA-Rs at some distance from the

$\leftarrow$

cordings made in the presence of NBQX, bicuculline, and TTX in the bath (same concentrations as in A). C, PF-EPSCs are blocked by NBQX. Averaged PF-EPSCs from one cell in control conditions (left) and in the presence of $10 \mu \mathrm{M}$ NBQX (right). D, CF-EPSCs display an NMDA-mediated component. Averaged CF-EPSCs recorded in control conditions (bicuculline only, left), after addition of $10 \mu \mathrm{M} \mathrm{NBQX} \mathrm{(middle),} \mathrm{and} \mathrm{in} \mathrm{the} \mathrm{presence} \mathrm{of} \mathrm{NBQX} \mathrm{plus} 50 \mathrm{~mm}$ D-APV (right). Inset, Superimposed scaled control-mediated (black) and NMDA-mediated (gray) CF-EPSCs. 


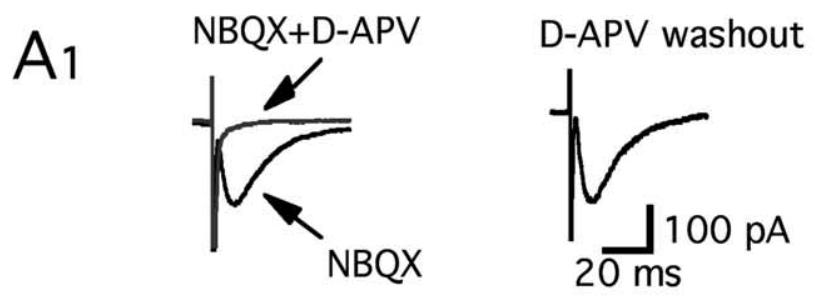

$\mathrm{A}_{2}$
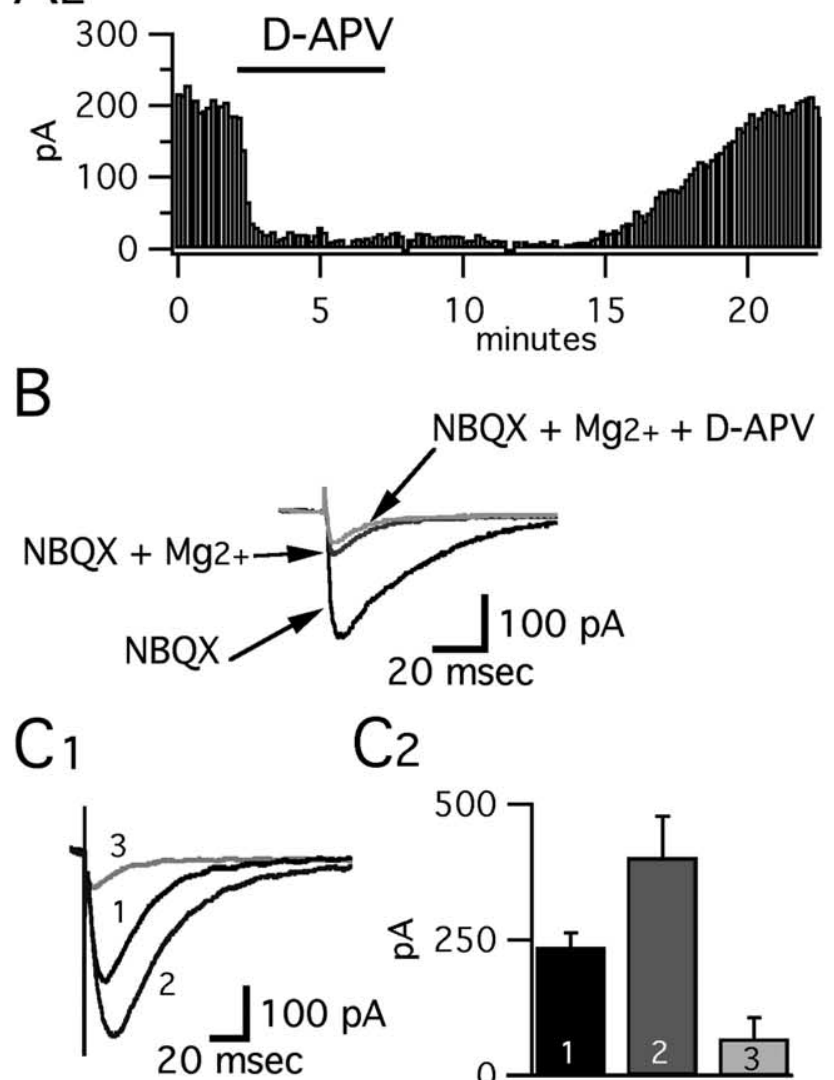

$\mathrm{C}_{2}$

D1
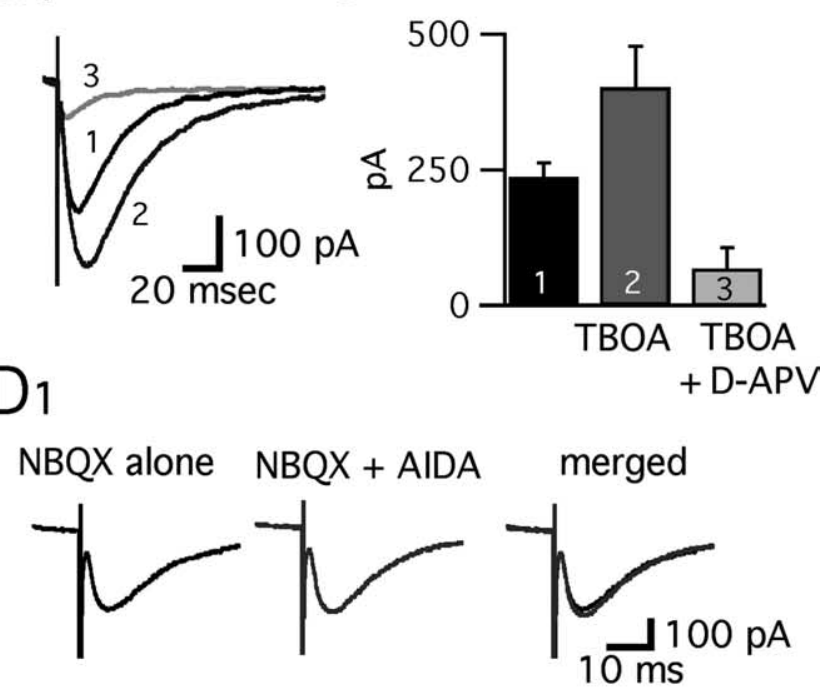

D2

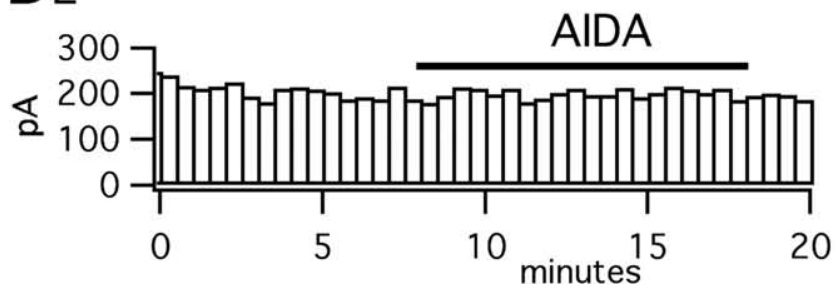

Figure 2. Most of the NBQX-resistant CF-EPSC is carried by NMDA-Rs in the absence of $\mathrm{Mg}^{2+}$.A, D-APV $(50 \mu \mathrm{m})$ reversibly blocks the NBQX-resistant CF-EPSC. A1, Averaged CF-EPSCS recorded in one cell before, during, and after the application of D-APV (as indicated on the traces). A2, Same cell as A1. Amplitude of the (F-EPSCs plotted over time; note the washout of D-APV. $B$, Effect of $\mathrm{Mg}^{2+}$ on the NBQX-resistant CF-EPSC. Superimposed averaged NBQXresistant CF-EPSCs recorded before and after addition of $1 \mathrm{~mm}$ external $\mathrm{Mg}^{2+}$ (as indicated on
A

\section{Standard internal internal MK801}
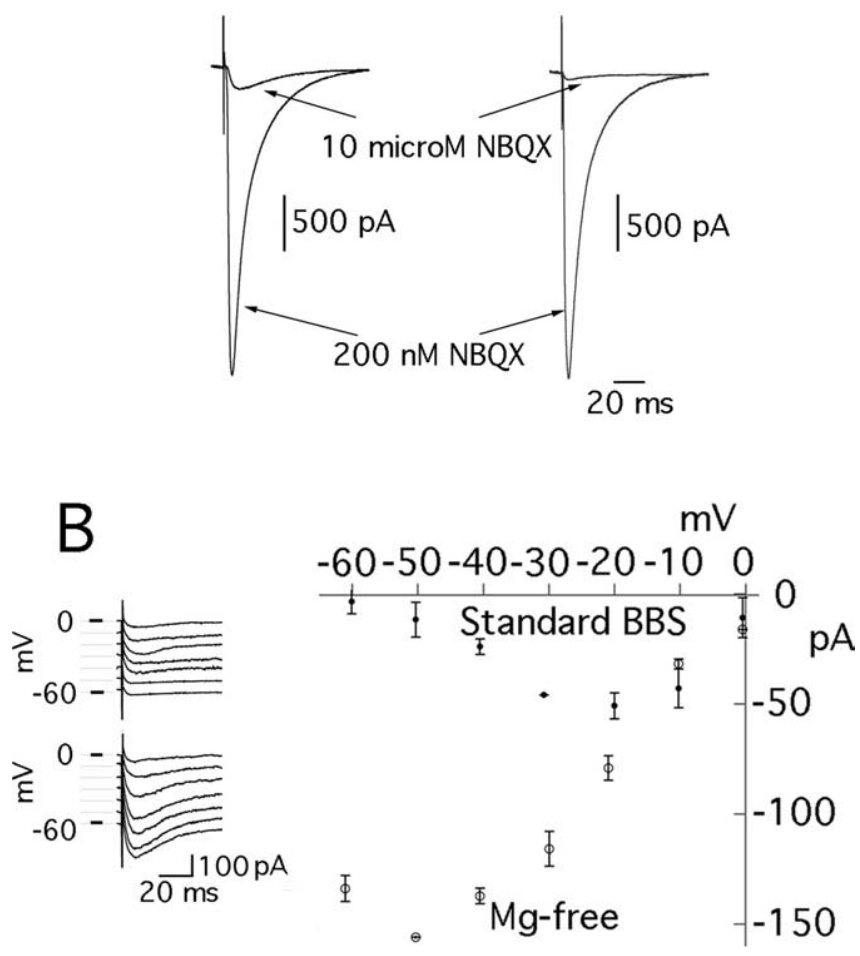

Figure 3. NMDA-mediated CF-EPSCS are postsynaptic. $\boldsymbol{A}$, Internal MK801 blocks the NBQXresistant CF-EPSC. Left, Averaged total CF-EPSCs recorded in one cell with standard K-based internal solution in the presence of $200 \mathrm{~nm} \mathrm{NBQX}$ to reduce voltage-clamp escape and after addition of $10 \mu \mathrm{m}$ NBQX. Right, Another cell recorded in the same conditions but with $3 \mathrm{~mm}$ MK801 added to the intracellular medium. Note that the infusion of MK801 in the Purkinje cell illustrated in the right blocks the NBQX-resistant CF-EPSC. $\boldsymbol{B}$, Left, NBQX-resistant CF-EPSCS recorded from one cell at different holding potentials (indicated on the left) to establish their $\mathrm{I}-V$ curve. Top traces, In the presence of external $\mathrm{Mg}^{2+}$; bottom traces, in nominally $\mathrm{Mg}^{2+}$ free BBS. Right, Corresponding / $-V$ curve established with the mean \pm SEM peak amplitude of three successive EPSCS recorded at a given potential, in the presence (filled circles; standard BBS) or in the absence of external $\mathrm{Mg}^{2+}$ (open circles; Mg-free).

releasing sites. This raises the possibility that, under conditions of saturation of glutamate transporters (i.e., sustained or repetitive glutamatergic synaptic transmission), NMDA receptors near CF terminals could be massively recruited.

In conclusion, there is no detectable contribution of indirect/polysynaptic NMDA currents to the NMDA-mediated CF-EPSC in our conditions. However, other neurotransmitters and/or mechanisms cannot be ruled out from a complex model of possible indirect NMDA currents. For this reason, it

$\leftarrow$

the traces) are shown. Additional application of $50 \mu \mathrm{m}$ D-APV does not further block the response. C, Blocking glutamate transporters with $100 \mu \mathrm{m}$ of DL-TBOA potentiates the NMDAmediated CF-EPSC. C1, Averaged NBQX-resistant CF-EPSCs (trace 1, black) are potentiated by TBOA (trace 2, dark gray). These potentiated responses are blocked by the final addition of 50 $\mu \mathrm{M}$ D-APV (trace 3, light gray) showing that they are carried by NMDA-Rs. C2, Mean \pm SEM amplitude ( $n=5$ cells) of the NMDA-mediated CF-EPSCs in control (NBQX at $10 \mu \mathrm{M}$ ), after addition of TBOA $(100 \mu \mathrm{m})$, and after further addition of D-APV $(50 \mu \mathrm{M})$. Numbers correspond to C1. D, Blocking group 1 mGluRs with AIDA (100 $\mu \mathrm{m})$ has no effect on the NBQX-resistant CF-EPSC. D1, Averaged NBQX-resistant CF-EPSCs in control (NBQX alone) and during bath application of AIDA (NBQX + AIDA). Sweeps are merged for comparison (right). D2, Amplitude of the NBQX-resistant CF-EPSC plotted over time before and during the application of AIDA (as indicated). 
was important to clarify the presynaptic or postsynaptic origin of the NMDA-mediated CF-EPSC with more direct approaches.

\section{Blocking postsynaptic NMDA-Rs inhibits the NMDA-mediated CF-EPSC}

Postsynaptic NMDA-Rs were blocked specifically in the recorded Purkinje cell by adding MK801 to the internal solution. MK801 is a pore blocker of NMDA-Rs that has been used successfully in the internal medium to block postsynaptic NMDA responses in single cells (Berretta and Jones, 1996; Humeau et al., 2003; Massey et al., 2004; Samson and Pare, 2005). MK801 was added to the internal medium (1 or $3 \mathrm{~mm}$ with no detectable differences), the climbing fiber was stimulated, and $10 \mu \mathrm{M}$ NBQX was added to the bath. The mean amplitude of the NBQX-resistant CF-EPSC was then estimated. With MK801 in the pipette, it was of $50.6 \pm 7.5$ pA $(n=9)$ on average, whereas it was of $228.9 \pm 25 \mathrm{pA}$ in controls (Fig. $3 A)(p<0.001)$. This remaining MK801-resistant current of $50.6 \pm 7.5 \mathrm{pA}$ was not further blocked by D-APV (50 $\mu \mathrm{M})$. Thus, postsynaptic MK801 has blocked all the NMDA component of the CF-EPSC.

These experiments show that the NMDA-mediated CF-EPSC is postsynaptic with no detectable presynaptic component. This conclusion, based on pharmacology, was further confirmed by analyzing the $I-V$ relationship of the NMDA-mediated CF-EPSCs.

\section{The $I-V$ relationship of the NMDA-mediated CF-EPSCs displays the typical $j$-shape of postsynaptic NMDA-Rs}

If the NMDA-mediated CF-EPSC is actually postsynaptic, its $I-V$ relationship is expected to display a negative slope between -70 and $-20 \mathrm{mV}$ in the presence of external $\mathrm{Mg}^{2+}$ (the $I-V$ curve is "j-shaped"). Changing the holding potential of Purkinje cells will relieve the $\mathrm{Mg}^{2+}$ block of postsynaptic but not of presynaptic NMDA-Rs. To address this issue, $I-V$ curves of the NMDAmediated CF-EPSCs were recorded in the presence or absence of external $\mathrm{Mg}^{2+}$.

Because of their very large and fully developed dendrites, it is not possible to accurately voltage clamp adult Purkinje cells (Llano et al., 1991). The situation is even worse at depolarized potentials, at which voltage-dependant ionic channels open, increasing voltage-clamp escape. Thus, one expects that the EPSCs recorded at positive potentials would be rather small and that their reversal potential would be above the theoretical value of 0 $\mathrm{mV}$. In these experiments, it was not possible to reduce this problem by pharmacologically blocking voltage-dependent $\mathrm{Na}^{+}$or $\mathrm{Ca}^{2+}$ channels: (1) the diffusion of internal channel blockers in the distal dendrites was not sufficient to prevent voltage-clamp escape, and (2) we could not use external blockers because they also inhibit neurotransmitter release. We therefore started the $I-V$ curve protocols at $0 \mathrm{mV}$, letting the voltage-dependent currents inactivate, and then progressively repolarized the cell to $-60 \mathrm{mV}$ (liquid junction estimated at $-12 \mathrm{mV}$ and corrected), focusing on the effect of external $\mathrm{Mg}^{2+}$ ions on the shape of the $I-V$ curve at these potentials. In standard $1 \mathrm{~mm}$ external $\mathrm{Mg}^{2+}$, for all cells tested, the $I-V$ curves displayed the typical j-shape of NMDA-mediated currents at negative potentials (Fig. 3B). In contrast, in nominally $\mathrm{Mg}^{2+}$-free external solution, for all but one of the Purkinje cells recorded ( $n=15)$, the NMDA-mediated CF-EPSCs displayed a linear $I-V$ relationship, with a positive slope between -50 and $0 \mathrm{mV}$ (Fig. 3B). A slight blockade of the NMDA-mediated EPSC was often still apparent at potentials below $-60 \mathrm{mV}$ in the $\mathrm{Mg}^{2+}$-free solution (Fig. 3B). This is probably attributable to the presence of contaminating $\mathrm{Mg}^{2+}$ ions that persist in slices.

These results confirm that the NMDA-mediated CF-EPSC is carried by postsynaptic NMDA-Rs.

\section{Immunolabeling reveals the presence of NR2-A/B subunits on Purkinje cells}

Our results imply the existence of functional NMDA-Rs on Purkinje cell membranes, i.e., of NMDA-Rs composed of heteromeric NR1/NR2 subunits, particularly in the vicinity of climbing fibers terminals. Although the expression of NR1 by adult Purkinje cells is well documented, that of NR2 subunits is less clear (for instance, see Yamada et al., 2001, as opposed to Thompson et al., 2000). We thus performed immunolabeling of the NR2 subunits, along with that of calbindin and VGluT2 as markers of Purkinje cells and climbing fibers terminals, respectively. Acquisition of the fluorescent signal with a confocal microscope revealed no labeling for NR2-C or NR2-D subunits in adult Purkinje cells, with any of the antibodies used (see Materials and Methods and data not illustrated). However, a clear and constant labeling of NR2-A/B subunits was found in Purkinje cell soma and proximal dendrites throughout the cerebellar vermis (Fig. 4). In the molecular layer, cells and dendrites labeled by NR2-A/B antibodies were almost exclusively calbindin positive (Fig. $4 B, C)$. In the first two-thirds of the molecular layer, corresponding to the zone of climbing fiber terminals, the NR2-A/B subunits were clearly concentrated in the Purkinje cell dendrites (Fig. 4). This NR2-A/B staining was homogenous throughout the lobules. It was present in either NR2-A/B single- or multiple-labeling experiments (Fig. 4), thereby excluding any interference from cross-reactions attributable to multiple-staining procedures. Because of the rather diffuse labeling of NR2-A/B in the overall Purkinje cells dendrites, nonconfocal images of the $60 \mu \mathrm{m}$ slices show a constant and diffuse staining of the molecular layer in which only soma and large dendrites of Purkinje cells were distinguishable. Confocal images observed in 1- $\mu \mathrm{m}$-spaced stacks revealed clear NR2-labeled dendrites (Fig. 4B). Threedimensional (3D) reconstructions of confocal stacks show strong labeling by NR2-A/B antibodies throughout the proximal dendrites (Fig. 4C). In the proximal dendrites of Purkinje cells observed at higher magnification, the labeling for NR2-A/B often coincided with VGluT2 labeling (Fig. 4D).

A lighter and more diffuse labeling of NR2-A/B was also observed in the distal dendrites of Purkinje cells, including in the upper third of the molecular layer, a zone of contacts exclusively between parallel fibers and Purkinje cells, as assessed by the absence of VGluT2 labeling in this zone (Fig. 4B,C). Although the labeling was less intense in this zone, this observation opens the possibility of the existence of some extrasynaptic NMDA-Rs on Purkinje cells near parallel fiber synapses. Alternatively, it could also correspond to some presynaptic NR2-A/B subunits. In the granular layer, NR2-A/B and VGluT2 labeling also coincide. This most probably corresponds to glomeruli, in which mossy fiber terminals express VGluT2 (Hioki et al., 2003) and granule cell dendrites NR2-A (as well as NR2-C that are not labeled by the present antibody) in mature animals (Akaike et al., 1981; Cathala et al., 2000). In agreement with the observation that mRNA for NR2-A and NR2-B subunits is absent from stellate and basket cells (Akazawa et al., 1994), no labeling was detected in these neurons.

Adult Purkinje cells express high levels of NR1 subunits (Petralia et al., 1994a; Hafidi and Hillman, 1997; Thompson et al., 2000). Thus, the description of some NR2 subunits in these cells 

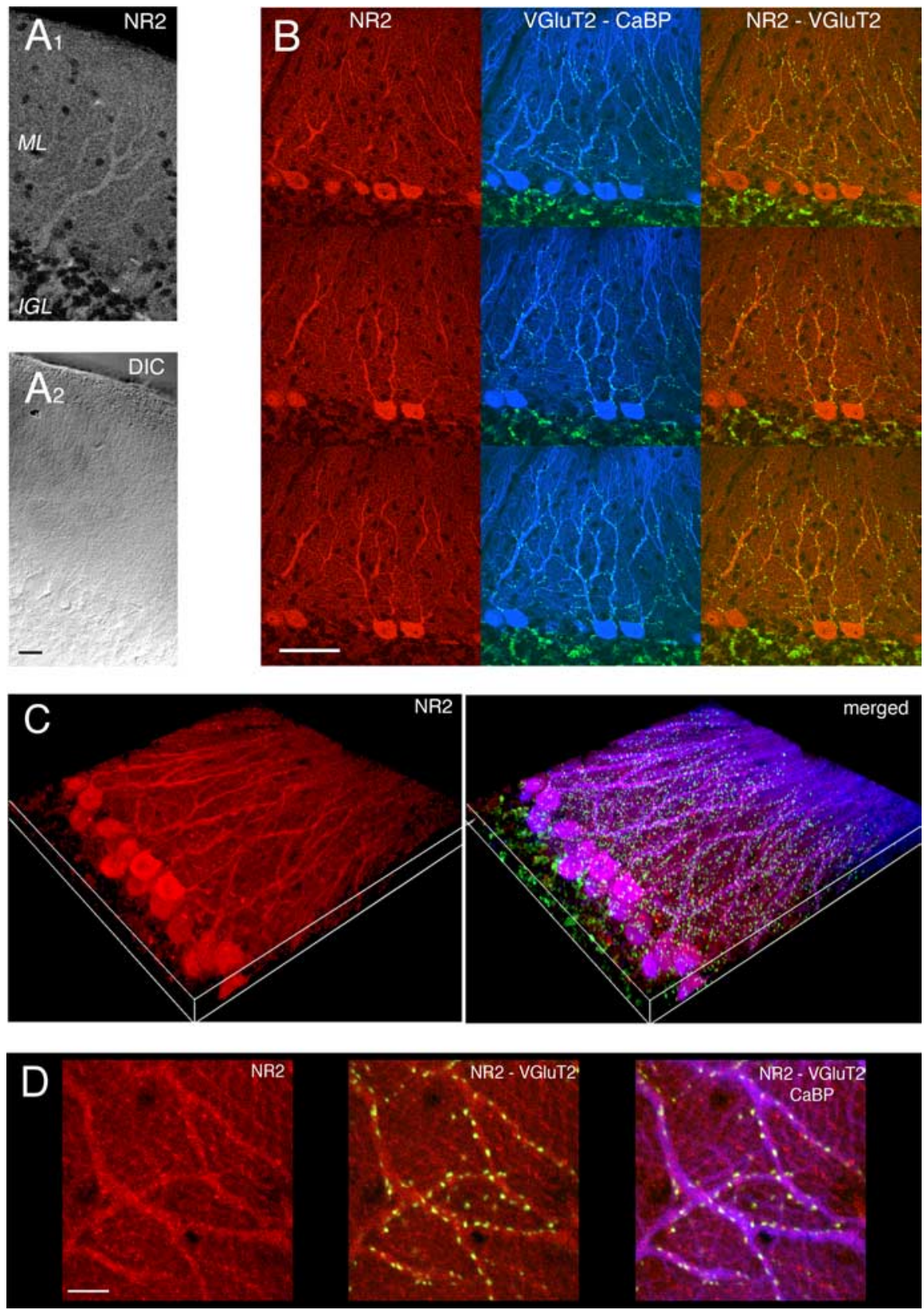

Figure 4. Distribution of NR2-A/B immunofluorescence on sagittal slices observed with confocal imaging. $A 1$, Single NR2-A/B immunolabeling showing the soma and primary dendrites of a Purkinje cell. $\mathbf{A 2}$, Same area observed in differential interference contrast microscopy (DIC). Scale bar, $20 \mu \mathrm{m}$. ML, Molecular layer; IGL, internal granular layer. Note the presence of presumably NR2-A at the level of glomeruli in the IGL. B, Successive 1- $\mu \mathrm{m}$-spaced confocal sections showing NR2-A/B (red), calbindin (CaBP, blue), as well as VGluT2 (green) labeling. Scale bar, $40 \mu \mathrm{m}$. C, Three-dimensional reconstruction of a stack of 30 successive $1-\mu \mathrm{m}$-spaced confocal sections displaying the NR2-A/B immunolabeling alone (left) and NR2-A/B (red) plus CaBP (blue) plus VGluT2 (green) merged (right). Same zone as in $\boldsymbol{B}$. Note that the merged 3D stack reveals that distal dendrites of Purkinje cell in the upper third of the molecular layer displays less intense immunoreactivity for NR2-A/B. D, High-power image $(4 \times)$ of CaBPpositive (blue) dendrites showing NR2-A/B (red) and VGluT2 (green). Scale bar, $10 \mu \mathrm{m}$.

is not surprising and confirms the presence functional NMDARs. In addition, supporting our data, the distribution of NR2-A/B labeling described here exactly matches that of NR1 subunits in Purkinje cells (Petralia et al., 1994a).

The NMDA component of the CF-EPSC appears at the end of 3 weeks $P N$ and progressively increases with Purkinje cell maturation

Our data converge toward the presence of NMDA-Rs in mature Purkinje cells from animals older than 8 weeks. Most of the au- thors that did not detect NMDA-Rs in fact worked with much younger animals. The developmental profile of the NMDAmediated CF-EPSC was therefore investigated by quantifying the effect of D-APV on the amplitude of the CF-EPSC recorded in $10 \mu \mathrm{M}$ NBQX from P12 to 12 weeks PN (see Materials and Methods). As illustrated in Figure 5B, the NMDAmediated component of CF-EPSCs can hardly be detected before P21. Both the number of cells displaying NMDAmediated CF-EPSC (Fig. 5B) and the mean amplitude of these NMDA currents increase from P18 to P21 (Fig. 5C), at least in the vermis, in which our recordings were performed. From P22, all the cells tested displayed significant NMDA-mediated CF-EPSCs, but their amplitudes were still rather modest and continued to increase, reaching $69.5 \pm 4.8 \%(n=7) 8$ weeks after birth (Fig. 5C). Taking into account cells from animals ranging in age from 12 weeks to 6 months, the mean blockade induced by D-APV was $87 \pm 5.5 \%$ (Fig. $5 C$ ). Thus, there is still a slight increase in the amplitude of the NMDA-mediated CF-EPSC after 8 weeks PN. These data show that the NMDA-mediated component of the CFEPSC appears by P21 but is still very small at this age, probably explaining the difficulty to detect these receptors in previous studies.

\section{CNQX partly blocks the \\ NMDA-mediated CF-EPSC}

The presence of functional NMDA-Rs in Purkinje cells and the existence of NMDA-mediated currents in CF-EPSCs were investigated previously mostly in immature animals (Perkel et al., 1990; Farrant and Cull-Candy, 1991; Llano et al., 1991); thus, the absence of detectable NMDA currents is not surprising considering our results. However, a study from Perkel et al. (1990) did not show any NMDA component in the CF-EPSCs of 4- to 6-week-old rats. Although species differences cannot be completely excluded, examination of this study shows that it was done using CNQX as a specific blocker of AMPA receptors. CNQX has been widely described as being also an antagonist at NMDA-Rs, in part by competing with glycine at its modulatory site (Birch et al., 1988; Harris and Miller, 1989; Kessler et al., 1989; Pellegrini-Giampietro et al., 1989; Lester and Jahr, 1990; Mead and Stephens, 1999) and also with glutamate at its binding site (Lester and Jahr, 1990). In contrast, NBQX has no effect on NMDA currents (Sheardown et al., 1990). We therefore studied the effect of CNQX on the NMDA-mediated CF-EPSC in mice older than 8 weeks at concentrations commonly used in cerebral tissue slices (Fig. 5D). At 10,20 , and $50 \mu \mathrm{M}$, the residual NMDA-mediated CF-EPSC 

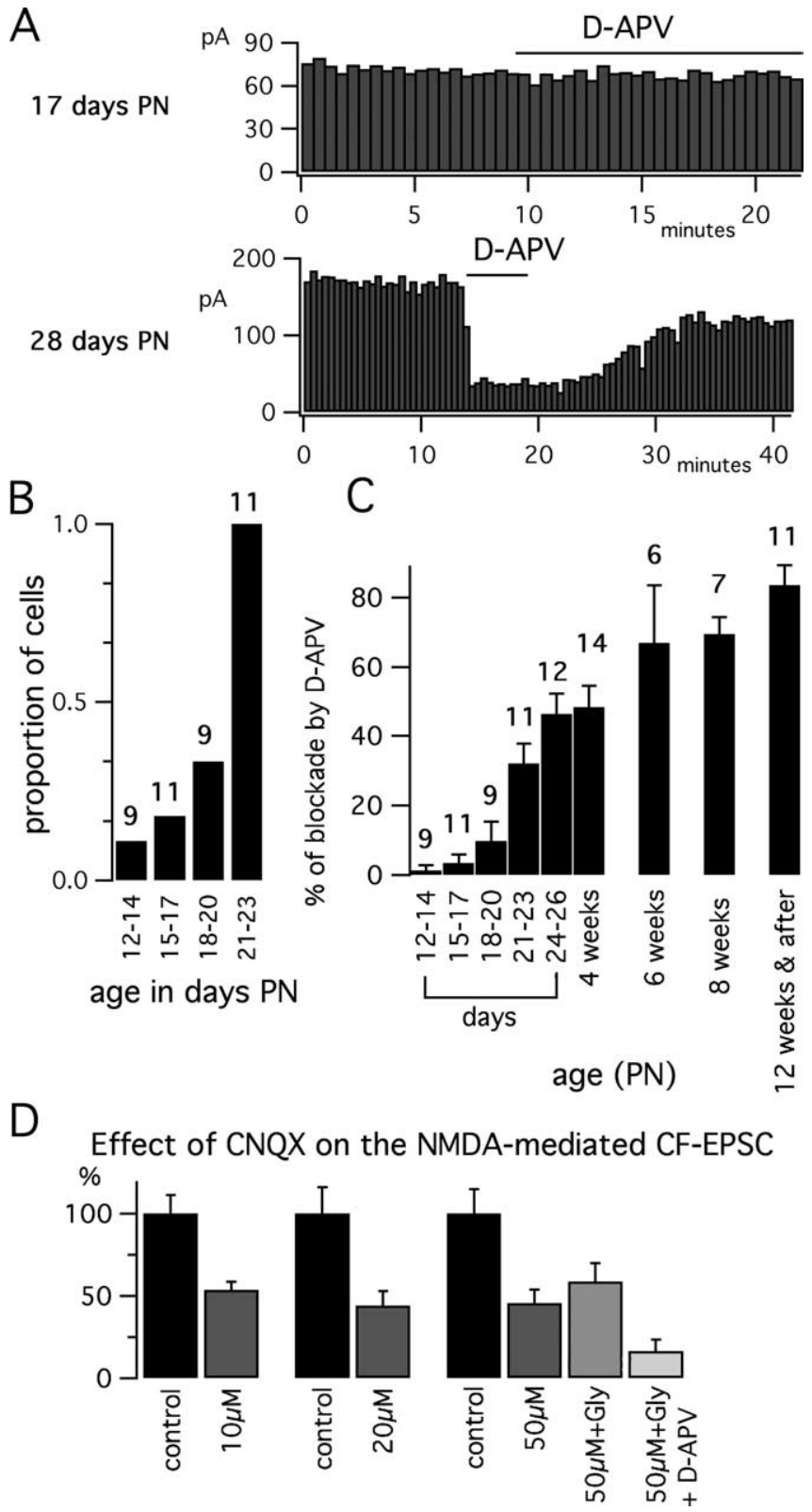

Figure 5. Development of the NMDA-mediated CF-EPSCs and their blockade by CNQX. $\boldsymbol{A}$, Amplitude of the NBQX-resistant CF-EPSC over time, in $\mathrm{Mg}^{2+}$-free external medium, in two different Purkinje cells from P17 and P26 mice. Addition of $50 \mu \mathrm{m}$ D-APV in the bath reversibly blocks the NBQX-resistant CF-EPSC at P26, whereas it has no effect at P17. B, Proportion of Purkinje cells displaying a detectable NMDA component, observed at different postnatal ages. The total number of cells $(n)$ recorded at each age is indicated above the bars. C, Percentage of blockade of the NBQX-resistant CF-EPSCs induced by D-APV $(50 \mu \mathrm{M})$ over the development. Ages are indicated at the bottom of the graph. The total number of cells recorded at each age is indicated above the bars. $\boldsymbol{D}$, Mean \pm SEM peak amplitude of the NBQX-resistant CF-EPSCs in control (10 $\mu \mathrm{m} \mathrm{NBQX}$ alone) and after addition of three different concentrations of CNQX (10,20, or $50 \mu \mathrm{m}$ as indicated). On the right, further application of $200 \mu \mathrm{m}$ glycine tends to reverse the blockade by CNQX. Final addition of D-APV blocks the response reduced by CNQX and partially reversed by glycine, showing that it is carried by NMDA-Rs.

was $105 \pm 10.4,107.4 \pm 21.3$, and $123.5 \pm 15.6 \mathrm{pA}$, respectively, compared with $194.8 \pm 20.1(n=6), 256.4 \pm 40(n=$ $5)$, and $270.5 \pm 16 \mathrm{pA}(n=4)$ in control periods. The residual responses in $50 \mu \mathrm{M}$ CNQX were partially reversed by $200 \mu \mathrm{M}$ glycine, as expected from the previously described competition between CNQX and glycine (Lester and Jahr, 1990). This response was further blocked by D-APV $(50 \mu \mathrm{M})$, showing that it was indeed mediated by NMDA-Rs (Fig. 5D). In conclusion, CNQX, a widely used AMPA/kainate antagonist, at usual doses, blocks approximately half of the NMDA-mediated CFEPSC, probably by competing with glycine and possibly with glutamate at their binding sites. Taking into account this inhibitory effect of CNQX on the NMDA current, together with the still small amplitude of this EPSC in young animals, our data predict that, in the presence of $10 \mu \mathrm{M}$ CNQX and at 4 weeks PN, the CF-EPSC should have an amplitude of $\sim 60 \mathrm{pA}$. This explains rather well why some authors, such as Perkel et al. (1990), did not detect these NMDA-Rs. The study from Krupa and Crepel (1990) is also interesting because they detected NMDA-Rs in adult rat Purkinje cells ( 8 weeks PN). The fact that only $25 \%$ of the Purkinje cells responded to NMDA in adults whereas $100 \%$ responded during the first week PN under the same experimental conditions is probably attributable to the differences in subunit composition of the NMDA-Rs at these two ages. The NR1/NR2-D NMDA-Rs is particularly easy to detect with exogenous glutamate compared with NR1/ NR2-A/B of the adults. In 1990, these different subunits and their properties were still unknown, and, compared with juvenile currents, the NMDA currents of the adults apparently decline with age. Interestingly, the authors themselves already proposed this hypothesis in their discussion (Krupa and Crepel, 1990, their second to last paragraph). In addition, this study was performed with intracellular voltage-clamp recordings, a technique that is less appropriate than patch clamp for the recording of currents.

NMDA-Rs contribute to the complex spike in mature animals The NMDA-mediated CF-EPSC is rather small compared with the AMPA-mediated CF-EPSC, which raises the question of the functional role of these receptors in Purkinje cell physiology. First, in adults, it is important to note that dendritic currents recorded at the soma are highly filtered and that voltage is improperly controlled in dendrites, resulting in an underestimation of the amplitude of the NMDA-mediated CF-EPSC. Second, the physiological effect of an ionic conductance does not entirely depend on its amplitude; the location of the channels may also be at least as important. To better estimate the potential physiological relevance of the NMDA-Rs of the adult Purkinje cell, we next switched to recordings in the current-clamp mode and stimulated the climbing fiber to record the characteristic response, the complex spike. In this mode, we found two categories of Purkinje cells: (1) silent cells (no spontaneous spiking activity) with a resting potential at approximately $-65 /-70 \mathrm{mV}$; and (2) cells with a resting potential at approximately $-55 \mathrm{mV}$ with intermittent periods of spontaneous spiking activity. Spontaneous activity complicated the estimation of the resting potential of cells and of the shape of complex spikes over time. Therefore, in spontaneously active cells, we injected a small negative current through the recording pipette to maintain the Purkinje cell membrane at approximately $-70 \mathrm{mV}$ and to prevent activity.

As expected, the stimulation of the climbing fiber induced an all-or-none complex spike that consisted of one large spike followed by two to five shorter spikelets at the top of a fast depolarization plateau (Eccles et al., 1966) (for review, see Schmolesky et al., 2002) (see Fig. 7). This fast plateau was followed by a slow afterdepolarization (ADP) (Schmolesky et al., 2005) (see Fig. 7A). The duration of the plateau and the number of spikelets were rather variable among cells, but, for each individual Purkinje cell, 

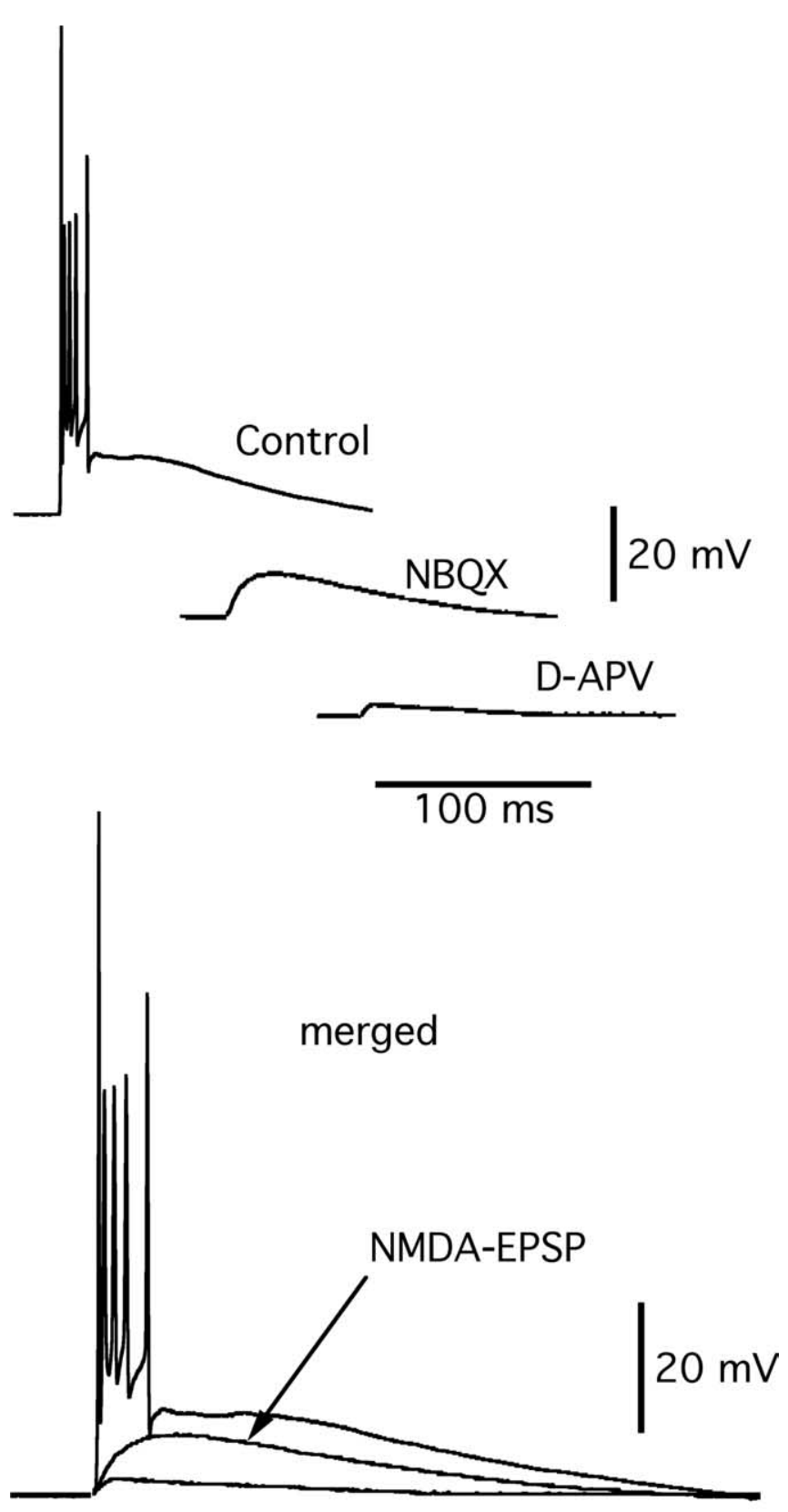

$100 \mathrm{~ms}$

Figure 6. Blocking the complex spike with NBQX reveals an NMDA-EPSP. Whole-cell currentclamp recording of a Purkinje cell from a mature animal (6 months old) in the absence of external $\mathrm{Mg}^{2+}$. Complex spike illustrated before (control) and after addition of NBQX (10 $\left.\mu \mathrm{M}\right)$. NBQX suppresses spikes and spikelets of the complex spike and reveals an NBQX-resistant CFEPSP (top middle trace) that is completely inhibited by $50 \mu \mathrm{m} \mathrm{D-APV}$ (top right trace). Note the kinetics of the complex spike and of NMDA-EPSP superimposed below.

at room temperature, the waveform of the complex spike was remarkably stable over time, even for long recordings (up to $1 \mathrm{~h}$ ). In some cases, an antidromic spike preceded the complex spike itself. The climbing fiber was stimulated at $0.1 \mathrm{~Hz}$, and the existence of an NMDA-mediated CF-EPSP was first investigated in magnesium-free BBS (Fig. 6). In this configuration, adding 10 $\mu \mathrm{M}$ NBQX to the bath while recording the complex spike suppressed spikes and spikelets, leaving a large NBQX-resistant CFEPSP (Fig. 6). This EPSP was completely abolished by D-APV (50 $\mu \mathrm{M})$ or $\mathrm{Mg}^{2+}(1 \mathrm{mM})$ in all the Purkinje cells tested $(n=7)$ (Fig.
6, right), showing that it is an NMDA-mediated CF-EPSP (NMDA-EPSP). This NMDA-EPSP was all or none, with a mean amplitude of $14 \pm 1.9 \mathrm{mV}(n=7)$ (Fig. 6, middle).

The contribution of this NMDA-EPSP to the complex spike was then investigated in more physiological conditions, i.e., in the presence of $1 \mathrm{~mm} \mathrm{Mg}^{2+}$ in the bath (Fig. 7). We measured five different parameters in the complex spike: the amplitude of the fast depolarization plateau (plateau), the amplitude of the ADP, the number of spikes and spikelets, their delays, and the membrane potential over time (Fig. 7) (table in supplemental Fig. 1, available at www.jneurosci.org as supplemental material). Eight cells were recorded at room temperature $\left(24-26^{\circ} \mathrm{C}\right)$, and three cells were recorded at $34^{\circ} \mathrm{C}$. In all these 11 cells, D-APV $(50 \mu \mathrm{M}$ added to the bath) had a significant effect on these parameters (table in supplemental Fig. 1, available at www.jneurosci.org as supplemental material). However, when present, the delay of the initial antidromic spike was not affected by D-APV, except for one cell in which it disappeared in D-APV and reappeared during washout. In all but one cell $(n=11)$, D-APV increased delays of spikes and spikelets (Fig. 7) (table in supplemental Fig. 1, available at www.jneurosci.org as supplemental material). At room temperature, the resting potential slightly but not significantly increased during D-APV application (Fig. 7A2). At $34^{\circ} \mathrm{C}$, this effect was more prominent. Because modest changes in membrane potential can significantly modify the complex spike waveform, we maintained the membrane potential at $-70 \mathrm{mV}$ during the entire recording to reliably compare the complex spikes during D-APV together with controls. In 7 of 11 cells, the increase in spike and spikelet delay ultimately led to a reduction in their number, thereby significantly changing the spike waveform (Fig. $7 B)$. In five of these cells, this change of waveform was too important to estimate the effect of D-APV on the plateau and ADP (table in supplemental Fig. 1, available at www.jneurosci.org as supplemental material). For the remaining six cells, D-APV reduced the amplitude of the depolarization plateau and of the ADP (Fig. 7A) (table in supplemental Fig. 1, available at www. jneurosci.org as supplemental material). All these effects of D-APV were fully reversible on washout, showing that they did not result from rundown over time (Fig. $7 B$ ). In 5 of 11 cells, this washout was accompanied by a rebound increase of the amplitude of the fast plateau and of the number of spikelets in the complex spike (as in example of Fig. $7 B$ ). The smaller the effects of D-APV were, the larger this rebound was. This indicates that, from the beginning of the experiment, some of the NMDA-Rs were already desensitized/inactivated, suggesting that there might be a tonic activation of the NMDA component, at least in our conditions.

In conclusion, blocking NMDA-Rs reduces the amplitude of the plateau and ADP, increases spike and spikelet latency, and, in some cases, reduces their number. What might cause these effects? In the complex spike, the latency of spikes depends, among other parameters, on the amplitude of the underlying potential: increasing the potential amplitude reduces latency because the threshold of discharge is reached faster. Thus, the magnitude of the latency shift induced by D-APV likely depends on the amplitude of the underlying NMDA potential. Furthermore, if the NMDA potential is large, the latency shift in D-APV will also be accompanied by the disappearance of some spikes or spikelets because their threshold will no longer be reached during the complex spike.

These results show that NMDA-Rs increase the depolarization induced by the complex spike and prolong its duration. These effects are likely to favor calcium entry in the dendrites 
as well as their propagation, and, because they occur in the presence of physiological concentrations of $\mathrm{Mg}^{2+}$ and near physiological temperature, NMDA-Rs are potent actors in the physiology of adult Purkinje cells.

\section{Discussion}

We demonstrate that Purkinje cells from adult mice respond to exogenous NMDA applications in the presence of TTX, bicuculline, and NBQX. In agreement with Sekiguchi et al. (1987), we show that Purkinje cells respond to ionophoresis of NMDA at their proximal but not their distal dendrites. Accordingly, we detect NMDA-Rs by immunohistochemistry in the lower two-thirds of the Purkinje cell dendrites, i.e., near climbing fiber synapses. Confirming these observations, NMDA receptors carry part of the CFEPSC. In $\mathrm{Mg}^{2+}$-free solution, the major part of the NBQX-resistant CF-EPSC is typical of NMDA currents, i.e., potentiation by glycine and blockade by D-APV, MK801, and external $\mathrm{Mg}^{2+}$ ions. Three direct lines of evidence demonstrate that the NMDA-mediated CF-EPSCs is postsynaptic: (1) the immunolabelings of NR2-A/B; (2) the blockade of NMDAmediated CF-EPSCs by internal MK801; and (3) their voltage-dependent block at hyperpolarized potentials in the presence, but not in the absence, of external $\mathrm{Mg}^{2+}$.

The NMDA-mediated CF-EPSC was present in all but one of the mature Purkinje cells tested in the study, showing that, in adult mice, it is a consistent component of climbing fiber to Purkinje cell synapses. How can discrepancies between our results and previous studies be explained? Differences among various species used cannot be completely excluded. However, NMDA-Rs have also been previously detected in guinea pig, rats, and humans (Quinlan and Davies, 1985; Billard and Pumain, 1989; Krupa and Crepel, 1990; Scherzer et al., 1997; Thompson et al., 2000). In light of our data, the difficulty in finding NMDA currents mainly results from (1) differences in the age of the animals, (2) the use of CNQX, and (3) the lack of information about properties of the different NMDA subunits at the time of these studies. In fact, most of the groups that looked for NMDA currents in adult Purkinje cells worked in animals younger than 3 weeks. However, we now show that the adult-type NMDA current is barely detectable before 3 weeks PN and remains small until 6 weeks. In addition, as observed previously in other cell types, CNQX blocks half of the NMDA-mediated CF-EPSC. Consequently, as long as the NMDA current remains relatively small, CNQX leaves a hardly detectable NMDA-mediated CF-EPSC. This probably explains why Perkel et al. (1990), for instance, did not detect the NMDA responses in their study performed using 4- to 6-week-old animals.

Many of the studies performed before 1990 in the "true adult"
A2 Afterdepolarization (ADP)

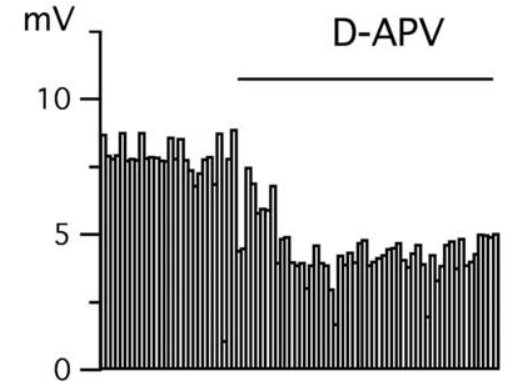

$\mathrm{mV}$

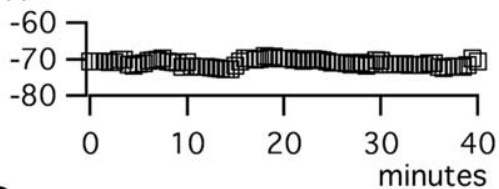

B2

Figure 7. NMDA-R contribution to the complex spike in standard $\left(1 \mathrm{mM} \mathrm{Mg}^{2+}\right) \mathrm{BBS}$. Whole-cell recordings from mature Purkinje cells in the presence of external $\mathrm{Mg}^{2+}(1 \mathrm{~mm})$ at room temperature. $\boldsymbol{A}$, Complex spikes recorded in bicuculline only stimulation onset. Note that D-APV reduces both the fast depolarization plateau (top) and the ADP. A2, Same cell as in $\boldsymbol{A} \boldsymbol{1}$. Pin se cell. B1, Complex spikes before (1), during (2), and after (3) the application of D-APV (50 $\mu \mathrm{M})$. In this cell, D-APV reduced plateau amplitude (arrows) and shifted the appearance of the spikelets (as in traces merged in bottom). B2, Same cell as $\boldsymbol{B 1}$. washout of D-APV (asterisk on the right trace of B1). This third spikelet occurred in the time window used to estimate the plateau amplitude, therefore causing the presence of peaks in the plot of amplitude of the plateau over time.

support our present data by indicating NMDA responses in Purkinje cells, although these studies provided only indirect evidence attributable to technical and pharmacological problems. Interestingly, some of them even provided evidence for the location of NMDA-Rs at climbing fibers synapses (Kimura et al., 1985; Quinlan and Davies, 1985; Sekiguchi et al., 1987; Billard and Pumain, 1989). Examination of these studies shows that they were not done with patch-clamp but with extracellular or intracellular microelectrode recordings. The two latter techniques are compatible with the use of adult animals, whereas patch-clamp studies prefer immature cells to ensure proper voltage clamp. Thus, the advent of patch-clamp technique in slices, by constraining authors to work in immature ("subadult") animals, 
likely contributed to the conclusion that adult Purkinje cells do not express functional NMDA-Rs.

Our data indicate that the NR2-A/B subunits of the adult replace neonatal NR2-D in Purkinje cells (Cull-Candy et al., 1998). Compared with NR2-A/B, NR2-D containing NMDA-Rs are less sensitive to $\mathrm{Mg}^{2+}$ block, do not desensitize, and slowly deactivate (Dingledine et al., 1999; Misra et al., 2000), which make them easy to detect with exogenous glutamate. Thus, the developmental switch from NR2-D to NR2$\mathrm{A} / \mathrm{B}$ in Purkinje cells renders the detection of NMDA-Rs much more difficult in adult Purkinje cells. This is probably why NMDA-Rs were evident in young animals but comparatively hard to detect in the same conditions later in the development (Dupont et al., 1987; Krupa and Crepel, 1990). Finally, the particular properties of NR2-D-containing NMDA-Rs make them poorly suited for classical fast synaptic transmission, contrary to NR2-A or NR2-B subunits. Accordingly, NR2-D are not components of neonatal climbing fiber synaptic transmission at P0-P4 (Lachamp et al., 2005), whereas NR2-A/B are expressed at mature climbing fiber connections. Thus, the translocation of the NMDA-Rs to the synapses during the development fits their respective biophysical characteristics.

What might be the role of these adult NMDA-Rs? Because of their well known characteristics, they are likely to modulate the integration or plasticity of Purkinje cells inputs and/or outputs or to play a role in the maintenance of their connections. Purkinje cells no longer respond to NMDA after climbing fiber deafferentation (Billard and Pumain, 1989). Conversely, we found adult NMDA-Rs at climbing fiber synapses from P21 in mice, i.e., an age that coincides with the complete regression of multiple climbing fiber innervation (Hashimoto and Kano, 2005). Thus, NMDA-Rs of adult Purkinje cells could play a role in the adjustment and/or maintenance of mature climbing fiber to Purkinje cells connections. It is also interesting to notice that $\mathrm{P} 21$ corresponds to the appearance of a mature form of retrograde signaling in Purkinje cell (Levenes et al., 2001; Crepel, 2007) and to the developmental transition stage when the spontaneous activity of Purkinje cells switches from tonic $\mathrm{Na}^{+}$spiking to a trimodal spiking pattern (combining $\mathrm{Na}^{+}$-spikes, $\mathrm{Ca}^{2+}$-spikes, and pauses) (McKay and Turner, 2005). Thus, from both a morphological and physiological point of view, the development of Purkinje cells of mice and a fortiori of rats is definitely not completed at P21 (Altman and Bayer, 1997; McKay and Turner, 2005).

Even in adults, NMDA currents are relatively small compared with the total CF-EPSC. However, this does not necessarily imply that NMDA-Rs have no physiological role. Experiments in current-clamp reveal an NMDA-EPSC of $14 \mathrm{mV}$ on average, which is not negligible. The fact that the complex spike displays an NMDA component in $1 \mathrm{mM} \mathrm{Mg}^{2+}$ containing $\mathrm{BBS}$ and at near physiological temperature indicate that these receptors contribute to the complex spike in physiological conditions. Importantly, this also demonstrates that the depolarization induced by the complex spike itself is sufficient to relieve the $\mathrm{Mg}^{2+}$ block of NMDA-Rs and to allow them to be activated by a single climbing fiber discharge.

Despite extensive studies, the informational role of the complex spike is still unclear (Simpson et al., 1996; Schmolesky et al., 2002). Depending on the study and on the research group, it is involved in real-time [like the "timing device” proposed by Llinas's group (Lang et al., 2006)], shortterm (modulation of the pause in fast spiking) (Simpson et al., 1996), or long-term modulation of Purkinje cells activity ("plasticity"). Whatever its role, the climbing fiber operates at the level of dendritic integration (input) and/or axonal firing patterns (output) of Purkinje cells. Looking at their contribution to the complex spike, NMDA-Rs may act at both levels.

The output of Purkinje cells after a complex spike consists of a burst of forward-propagating action potentials in the axon (Llinas and Sasaki, 1989; Khaliq and Raman, 2005). Propagation of the fast initial spike is highly reliable (Khaliq and $\mathrm{Ra}-$ man, 2005), but that of individual spikelets is much less reliable and subject to modulation. Propagation probability varies predictably with the spikelets waveform and can be described as a saturating function of spikelet amplitude, rate of rise, or preceding interspike interval (Khaliq and Raman, 2005). As we show, NMDA-Rs decrease the delay of the spikelets and, in most of the cells, increase their number, thereby changing interspike intervals. Thus, according to Khaliq and Raman (2005), the NMDA-mediated component of the complex spike is likely to change the probability of propagating spikelets in the axon.

Parallel fiber inputs to Purkinje cells display long-term depression (LTD) or potentiation (LTP). Probability of LTD versus LTP at parallel fiber inputs is under control of the climbing fiber (Coesmans et al., 2004), which itself undergoes calcium-dependent LTD (Hansel and Linden, 2000). As we show here, NMDA-Rs increase the depolarization induced by the complex spike and prolong its duration. These effects are expected to favor calcium entry in the dendrites as well as their propagation. Thus, NMDA-Rs are likely to be players in the game of mature Purkinje cells plasticity. However, it is difficult to evaluate from previous studies whether this is the case, because the molecular actors of Purkinje cell plasticity have been primarily investigated in immature cerebellar slices, i.e., before the expression of NMDA-Rs at climbing fiber synapses. Thus, it now remains to be established the exact role of the NMDA-Rs of the Purkinje cells, provided that the basic cellular rules of plasticity are reappraised in the context of mature cerebellar cortex.

\section{References}

Akaike A, Sasa M, Takaori S (1981) Inhibition from ventral tegmental area of nucleus accumbens neurons in the rat. Brain Res 225:189-194.

Akazawa C, Shigemoto R, Bessho Y, Nakanishi S, Mizuno N (1994) Differential expression of five $N$-methyl-D-aspartate receptor subunit mRNAs in the cerebellum of developing and adult rats. J Comp Neurol 347:150-160.

Altman J, Bayer SA (1997) Development of the cerebellar system. New York: CRC.

Auger C, Attwell D (2000) Fast removal of synaptic glutamate by postsynaptic transporters. Neuron 28:547-558.

Berretta N, Jones RS (1996) Tonic facilitation of glutamate release by presynaptic $N$-methyl-D-aspartate autoreceptors in the entorhinal cortex. Neuroscience 75:339-344.

Billard JM, Pumain R (1989) Loss of N-methyl-D-aspartate sensitivity of cerebellar Purkinje cells after climbing fiber deafferentation. An in vivo study in the rat. Neurosci Lett 106:199-204.

Birch PJ, Grossman CJ, Hayes AG (1988) 6,7-Dinitro-quinoxaline-2,3-dion and 6-nitro,7-cyano-quinoxaline-2,3-dion antagonise responses to NMDA in the rat spinal cord via an action at the strychnine-insensitive glycine receptor. Eur J Pharmacol 156:177-180.

Cathala L, Misra C, Cull-Candy S (2000) Developmental profile of the changing properties of NMDA receptors at cerebellar mossy fiber-granule cell synapses. J Neurosci 20:5899-5905.

Clark BA, Cull-Candy SG (2002) Activity-dependent recruitment of extrasynaptic NMDA receptor activation at an AMPA receptor-only synapse. J Neurosci 22:4428-4436.

Coesmans M, Weber JT, De Zeeuw CI, Hansel C (2004) Bidirectional par- 
allel fiber plasticity in the cerebellum under climbing fiber control. Neuron 44:691-700.

Crepel F (2007) Developmental changes in retrograde messengers involved in depolarization-induced suppression of excitation at parallel fiberPurkinje cell synapses in rodents. J Neurophysiol 97:824-836.

Crepel F, Dhanjal SS, Sears TA (1982) Effect of glutamate, aspartate and related derivatives on cerebellar Purkinje cell dendrites in the rat: an in vitro study. J Physiol (Lond) 329:297-317.

Cull-Candy SG, Brickley SG, Misra C, Feldmeyer D, Momiyama A, Farrant M (1998) NMDA receptor diversity in the cerebellum: identification of subunits contributing to functional receptors. Neuropharmacology 37:1369-1380.

Cull-Candy S, Brickley S, Farrant M (2001) NMDA receptor subunits: diversity, development and disease. Curr Opin Neurobiol 11:327-335.

Diez-Garcia J, Matsushita S, Mutoh H, Nakai J, Ohkura M, Yokoyama J, Dimitrov D, Knopfel T (2005) Activation of cerebellar parallel fibers monitored in transgenic mice expressing a fluorescent $\mathrm{Ca}^{2+}$ indicator protein. Eur J Neurosci 22:627-635.

Dingledine R, Borges K, Bowie D, Traynelis SF (1999) The glutamate receptor ion channels. Pharmacol Rev 51:7-61.

Dupont JL, Gardette R, Crepel F (1987) Postnatal development of the chemosensitivity of rat cerebellar Purkinje cells to excitatory amino acids. An in vitro study. Brain Res 431:59-68.

Eccles JC, Llinas R, Sasaki K (1966) The excitatory synaptic action of climbing fibres on the purkinje cells of the cerebellum. J Physiol (Lond) 182: $268-296$.

Farrant M, Cull-Candy SG (1991) Excitatory amino acid receptor-channels in Purkinje cells in thin cerebellar slices. Proc R Soc Lond B Biol Sci 244:179-184.

Garthwaite G, Yamini Jr B, Garthwaite J (1987) Selective loss of Purkinje and granule cell responsiveness to $N$-methyl-D-aspartate in rat cerebellum during development. Brain Res 433:288-292.

Glitsch M, Marty A (1999) Presynaptic effects of NMDA in cerebellar Purkinje cells and interneurons. J Neurosci 19:511-519.

Hafidi A, Hillman DE (1997) Distribution of glutamate receptors GluR 2/3 and NR1 in the developing rat cerebellum. Neuroscience 81:427-436.

Hansel C, Linden DJ (2000) Long-term depression of the cerebellar climbing fiber-Purkinje neuron synapse. Neuron 26:473-482.

Harris KM, Miller RJ (1989) CNQX (6-cyano-7-nitroquinoxaline-2,3dione) antagonizes NMDA-evoked $\left[{ }^{3} \mathrm{H}\right] \mathrm{GABA}$ release from cultured cortical neurons via an inhibitory action at the strychnine-insensitive glycine site. Brain Res 489:185-189.

Hashimoto K, Kano M (2005) Postnatal development and synapse elimination of climbing fiber to Purkinje cell projection in the cerebellum. Neurosci Res 53:221-228.

Hioki H, Fujiyama F, Taki K, Tomioka R, Furuta T, Tamamaki N, Kaneko T (2003) Differential distribution of vesicular glutamate transporters in the rat cerebellar cortex. Neuroscience 117:1-6.

Huang YH, Dykes-Hoberg M, Tanaka K, Rothstein JD, Bergles DE (2004) Climbing fiber activation of EAAT4 transporters and kainate receptors in cerebellar Purkinje cells. J Neurosci 24:103-111.

Humeau Y, Shaban H, Bissiere S, Luthi A (2003) Presynaptic induction of heterosynaptic associative plasticity in the mammalian brain. Nature 426:841-845.

Kessler M, Baudry M, Lynch G (1989) Quinoxaline derivatives are highaffinity antagonists of the NMDA receptor-associated glycine sites. Brain Res 489:377-382.

Khaliq ZM, Raman IM (2005) Axonal propagation of simple and complex spikes in cerebellar Purkinje neurons. J Neurosci 25:454-463.

Kimura H, Okamoto K, Sakai Y (1985) Pharmacological evidence for L-aspartate as the neurotransmitter of cerebellar climbing fibres in the guinea-pig. J Physiol (Lond) 365:103-119.

Konnerth A, Llano I, Armstrong CM (1990) Synaptic currents in cerebellar Purkinje cells. Proc Natl Acad Sci USA 87:2662-2665.

Krupa M, Crepel F (1990) Transient sensitivity of rat cerebellar Purkinje cells to $N$-methyl-D-aspartate during development. A voltage clamp study in in vitro slices. Eur J Neurosci 2:312-316.

Lachamp P, Balland B, Tell F, Baude A, Strube C, Crest M, Kessler JP (2005) Early expression of AMPA receptors and lack of NMDA receptors in developing rat climbing fibre synapses. J Physiol (Lond) 564:751-763.

Lang EJ, Sugihara I, Llinas R (2006) Olivocerebellar modulation of motor cortex ability to generate vibrissal movements in rat. J Physiol (Lond) 571:101-120.

Laurie DJ, Seeburg PH (1994) Regional and developmental heterogeneity in splicing of the rat brain NMDAR1 mRNA. J Neurosci 14:3180-3194.

Lester RA, Jahr CE (1990) Quisqualate receptor-mediated depression of calcium currents in hippocampal neurons. Neuron 4:741-749.

Levenes C, Daniel H, Crepel F (2001) Retrograde modulation of transmitter release by postsynaptic subtype 1 metabotropic glutamate receptors in the rat cerebellum. J Physiol (Lond) 537:125-140.

Llano I, Marty A, Armstrong CM, Konnerth A (1991) Synaptic-and agonistinduced excitatory currents of Purkinje cells in rat cerebellar slices. J Physiol (Lond) 434:183-213.

Llinas R, Sasaki K (1989) The functional organization of the olivo-cerebellar system as examined by multiple Purkinje cell recordings. Eur J Neurosci 1:587-602.

Massey PV, Johnson BE, Moult PR, Auberson YP, Brown MW, Molnar E, Collingridge GL, Bashir ZI (2004) Differential roles of NR2A- and NR2B-containing NMDA receptors in cortical long-term potentiation and long-term depression. J Neurosci 24:7821-7828.

McKay BE, Turner RW (2005) Physiological and morphological development of the rat cerebellar Purkinje cell. J Physiol (Lond) 567:829-850.

Mead AN, Stephens DN (1999) CNQX but not NBQX prevents expression of amphetamine-induced place preference conditioning: a role for the glycine site of the NMDA receptor, but not AMPA receptors. J Pharmacol Exp Ther 290:9-15.

Misra C, Brickley SG, Wyllie DJ, Cull-Candy SG (2000) Slow deactivation kinetics of NMDA receptors containing NR1 and NR2D subunits in rat cerebellar Purkinje cells. J Physiol (Lond) 525:299-305.

Monyer H, Sprengel R, Schoepfer R, Herb A, Higuchi M, Lomeli H, Burnashev N, Sakmann B, Seeburg PH (1992) Heteromeric NMDA receptors: molecular and functional distinction of subtypes. Science 256:1217-1221.

Monyer H, Burnashev N, Laurie DJ, Sakmann B, Seeburg PH (1994) Developmental and regional expression in the rat brain and functional properties of four NMDA receptors. Neuron 12:529-540.

Mori H, Mishina M (2003) Roles of diverse glutamate receptors in brain functions elucidated by subunit-specific and region-specific gene targeting. Life Sci 74:329-336.

Moriyoshi K, Masu M, Ishii T, Shigemoto R, Mizumo N, Nakanishi S (1991) Molecular cloning and characterization of the rat NMDA receptor. Nature 354:31-37.

Nakagawa S, Watanabe M, Inoue Y (1996) Altered gene expression of the $\mathrm{N}$-methyl-D-aspartate receptor channel subunits in Purkinje cells of the staggerer mutant mouse. Eur J Neurosci 8:2644-2651.

Otis TS, Kavanaugh MP, Jahr CE (1997) Postsynaptic glutamate transport at the climbing fiber-Purkinje cell synapse. Science 277:1515-1518.

Pellegrini-Giampietro DE, Galli A, Alesiani M, Cherici G, Moroni F (1989) Quinoxalines interact with the glycine recognition site of NMDA receptors: studies in guinea-pig myenteric plexus and in rat cortical membranes. Br J Pharmacol 98:1281-1286.

Perkel DJ, Hestrin S, Sah P, Nicoll RA (1990) Excitatory synaptic currents in Purkinje cells. Proc R Soc Lond B Biol Sci 241:116-121.

Petralia R, Yokotani N, Wenthold R (1994a) Light and electron microscope distribution of the NMDA receptor subunit NMDAR1 in the rat nervous system using a selective anti-peptide antibody. J Neurosci 14:667-696.

Petralia RS, Wang YX, Wenthold RJ (1994b) The NMDA receptor subunits NR2A and NR2B show histological and ultrastructural localization patterns similar to those of NR1. J Neurosci 14:6102-6120.

Quinlan JE, Davies J (1985) Excitatory and inhibitory responses of Purkinje cells, in the rat cerebellum in vivo, induced by excitatory amino acids. Neurosci Lett 60:39-46.

Rosenmund C, Legendre P, Westbrook GL (1992) Expression of NMDA channels on cerebellar Purkinje cells acutely dissociated from newborn rats. J Neurophysiol 68:1901-1905.

Samson RD, Pare D (2005) Activity-dependent synaptic plasticity in the central nucleus of the amygdala. J Neurosci 25:1847-1855.

Scherzer CR, Landwehrmeyer GB, Kerner JA, Standaert DG, Hollingsworth ZR, Daggett LP, Velicelebi G, Penney Jr JB, Young AB (1997) Cellular distribution of NMDA glutamate receptor subunit mRNAs in the human cerebellum. Neurobiol Dis 4:35-46.

Schmolesky MT, Weber JT, De Zeeuw CI, Hansel C (2002) The making of a complex spike: ionic composition and plasticity. Ann NY Acad Sci 978:359-390. 
Schmolesky MT, De Zeeuw CI, Hansel C (2005) Climbing fiber synaptic plasticity and modifications in Purkinje cell excitability. Prog Brain Res 148:81-94.

Sekiguchi M, Okamoto K, Sakai Y (1987) NMDA-receptors on Purkinje cell dendrites in guinea pig cerebellar slices. Brain Res 437:402-406.

Sheardown MJ, Nielsen EO, Hansen AJ, Jacobsen P, Honore T (1990) 2,3Dihydroxy-6-nitro-7-sulfamoyl-benzo(F)quinoxaline: a neuroprotectant for cerebral ischemia. Science 247:571-574.

Shimamoto K, Lebrun B, Yasuda-Kamatani Y, Sakaitani M, Shigeri Y, Yumoto N, Nakajima T (1998) DL-threo-beta-benzyloxyaspartate, a potent blocker of excitatory amino acid transporters. Mol Pharmacol 53:195-201.

Shin JH, Linden DJ (2005) An NMDA receptor/nitric oxide cascade is involved in cerebellar LTD but is not localized to the parallel fiber terminal. J Neurophysiol 94:4281-4289.
Simpson JI, Wylie DR, De Zeeuw CI (1996) On climbing fiber signals and their consequence(s). Behav Brain Sci 19:368-383.

Thompson CL, Drewery DL, Atkins HD, Stephenson FA, Chazot PL (2000) Immunohistochemical localization of $N$-methyl-D-aspartate receptor NR1, NR2A, NR2B and NR2C/D subunits in the adult mammalian cerebellum. Neurosci Lett 283:85-88.

Wadiche JI, Jahr CE (2001) Multivesicular release at climbing fiberPurkinje cell synapses. Neuron 32:301-313.

Watanabe M, Mishina M, Inoue Y (1994) Distinct spatiotemporal expressions of five NMDA receptor channel subunit mRNAs in the cerebellum. J Comp Neurol 343:513-519.

Yamada K, Fukaya M, Shimizu H, Sakimura K, Watanabe M (2001) NMDA receptor subunits GluRepsilon1, GluRepsilon3 and GluRzeta1 are enriched at the mossy fibre-granule cell synapse in the adult mouse cerebellum. Eur J Neurosci 13:2025-2036. 